\title{
Bedform signature of a West Antarctic palaeo-ice stream reveals a multi-temporal record of flow and substrate control
}

\author{
Alastair G.C. Graham ${ }^{\mathrm{a}, *}$, Robert D. Larter ${ }^{\mathrm{a}}$, Karsten Gohl ${ }^{\mathrm{b}}$, Claus-Dieter Hillenbrand ${ }^{\mathrm{a}}$, \\ James A. Smith ${ }^{\text {a }}$, Gerhard Kuhn ${ }^{\mathrm{b}}$ \\ a British Antarctic Survey, Geological Sciences Division, High Cross, Madingley Road, Cambridge CB3 OET, UK \\ ${ }^{\mathrm{b}}$ Alfred-Wegener-Institut für Polar- und Meeresforschung, Postfach 120161, D-27515 Bremerhaven, Germany
}

\section{A R T I C L E I N F O}

Article history:

Received 9 March 2009

Received in revised form

6 July 2009

Accepted 9 July 2009

\begin{abstract}
A B S T R A C T
The presence of a complex bedform arrangement on the sea floor of the continental shelf in the western Amundsen Sea Embayment, West Antarctica, indicates a multi-temporal record of flow related to the activity of one or more ice streams in the past. Mapping and division of the bedforms into distinct landform assemblages reveals their time-transgressive history, which implies that bedforms can neither be considered part of a single downflow continuum nor a direct proxy for palaeo-ice velocity, as suggested previously. A main control on the bedform imprint is the geology of the shelf, which is divided broadly between rough bedrock on the inner shelf, and smooth, dipping sedimentary strata on the middle to outer shelf. Inner shelf bedform variability is well preserved, revealing information about local, complex basal ice conditions, meltwater flow, and ice dynamics over time. These details, which are not apparent at the scale of regional morphological studies, indicate that past ice streams flowed across the entire shelf at times, and often had onset zones that lay within the interior of the Antarctic Ice Sheet today. In contrast, highly elongated subglacial bedforms on sedimentary strata of the middle to outer shelf represent a timeslice snapshot of the last activity of ice stream flow, and may be a truer representation of fast palaeo-ice flow in these locations. A revised model for ice streams on the shelf captures complicated multi-temporal bedform patterns associated with an Antarctic palaeo-ice stream for the first time, and confirms a strong substrate control on a major ice stream system that drained the West Antarctic Ice Sheet during the Late Quaternary.
\end{abstract}

(c) 2009 Elsevier Ltd. All rights reserved.

\section{Introduction and background}

The instability of the polar ice sheets and the threat of future sea level rise from their complete or partial collapse are topics of societal, economic and scientific importance (IPCC, 2007). Ice streams, the arterial channels of fast-flow that discharge the majority of ice and sediment from ice sheets, are a key if not dominant control on their mass balance and stability (Bentley, 1987; Bennett, 2003; Ó Cofaigh et al., 2007). Over the past decade, some major ice streams in Greenland and Antarctica have exhibited dramatic thinning (Shepherd et al., 2004), retreat, widening, and flow acceleration (Rignot and Jacobs, 2002; Joughin et al., 2003; Rignot, 2008). Recent changes are particularly apparent in the Amundsen Sea Embayment (ASE), West Antarctica (Fig. 1) where a combination of warm Circumpolar Deep Water upwelling onto the continental shelf, reverse gradient basal slopes, and ice

\footnotetext{
* Corresponding author. Tel.: +44 1223221 604; fax: +44 1223221646 .

E-mail address: alah@bas.ac.uk (A.G.C. Graham).
}

grounding below sea level may make the West Antarctic Ice Sheet (WAIS) susceptible to rapid deglaciation (Vaughan, 2008). To estimate the potential risk of a future WAIS collapse, ice sheet models capable of an accurate reconstruction of past dynamical changes are required (e.g. Vaughan and Arthern, 2007). Reconstructions of ice streams at the Last Glacial Maximum (LGM), when the WAIS had advanced onto the continental shelf, form a key component of and test for such models, and therefore data on them are urgently needed (IPCC, 2007).

Understanding the behaviour of and controls on fast-flow is currently a major challenge for ice sheet investigations. Subglacial geology has been recognised as a strong influence on some ice streams, where their activity is affected by the underlying topography, deeper structure (Anandakrishnan et al., 1998), and geology at the ice-bed interface (Bamber et al., 2006). Many ice streams are known to be underlain by a layer of soft, dilatant, deformable sediments which facilitates fast ice motion and high ice discharge (Boulton and Hindmarsh, 1987; Blankenship et al., 1987; Engelhardt et al., 1990; Kamb, 2001). Outside of these streams, regions of slower ice flow often correlate with rugged beds characterised by 


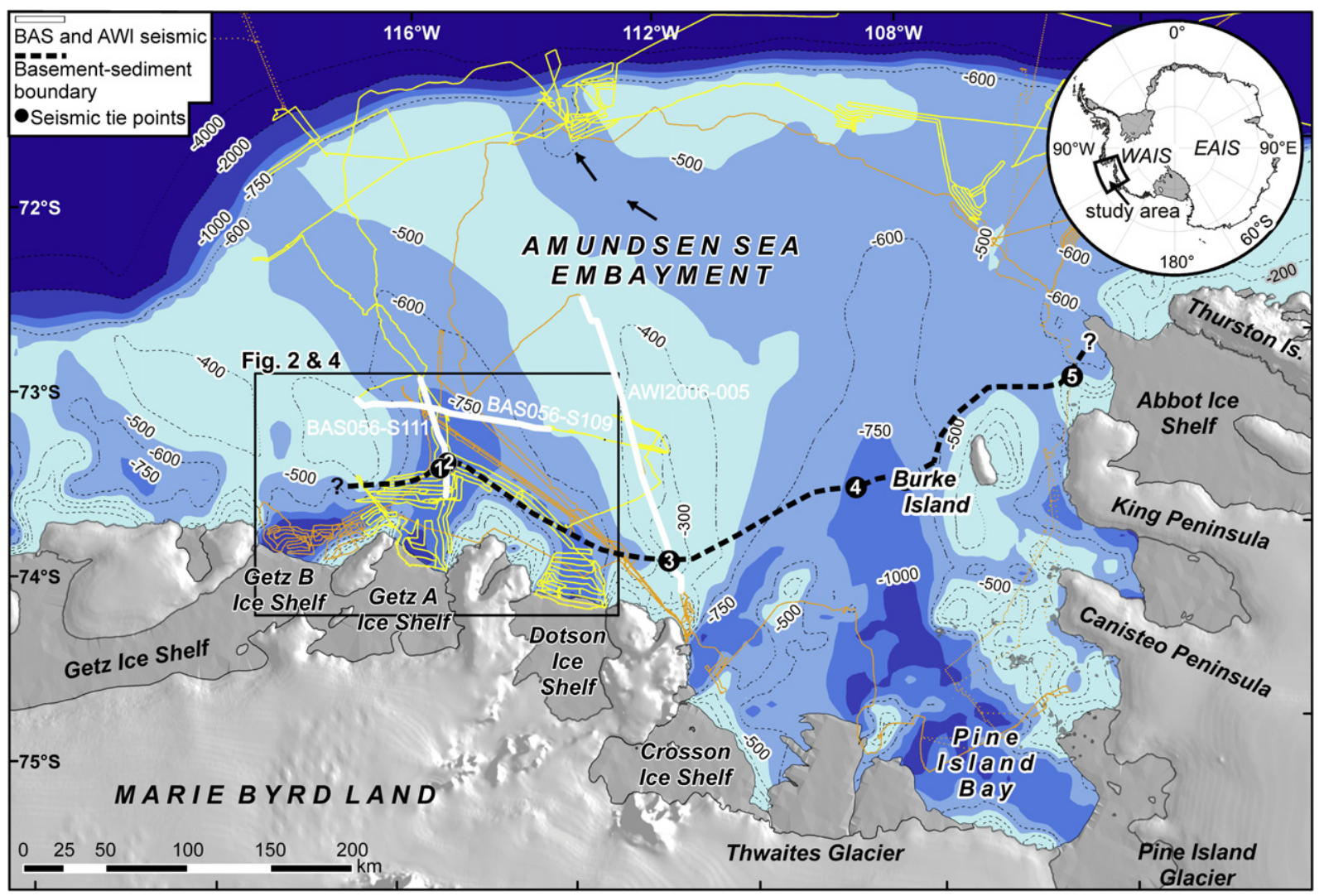

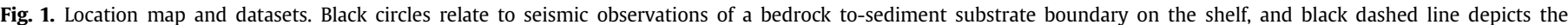

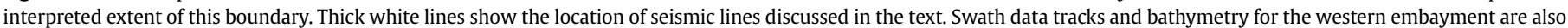

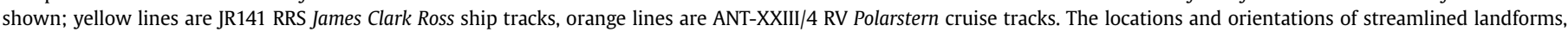

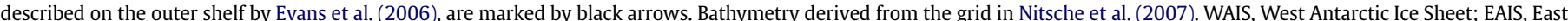
Antarctic Ice Sheet.

sedimentary rocks or crystalline bedrock. Indeed, changes observed in contemporary ice streams may have their roots in processes operating at the ice-bed, and in the lithological properties of their substrate (e.g. Peters et al., 2006).

However, this simple fast-sediment/slow-bedrock model may not be the complete picture. Recent discoveries of complex, patchwork basal conditions in the main trunk of the Rutford Ice Stream suggest strong local variability can characterise some Antarctic ice stream beds (Smith and Murray, 2009). Flow there appears to comprise of a local mixture of sliding over stiffer material and deformation on or within a water-saturated 'weak' till, and this variability is reflected both within the subglacial sediment layer and in the bedforms at the ice-base. Nonetheless, most ice stream beds are inaccessible for in situ studies, and further knowledge of the relationships between basal conditions (e.g. basal drag/flow mechanics), ice dynamics, and bedforms is therefore required. Exposed palaeo-ice stream beds provide an opportunity to improve our understanding of complex bed controls on ice flow (Ó Cofaigh et al., 2005a; King et al., 2007; Ottesen et al., 2008; ) by investigating sediment and bedform signatures over wide areas and over varying substrates.

Here, we describe the bedform signature and inferred flow character of a large palaeo-ice stream system in the western ASE. Previous work on palaeo-ice flow in the ASE using marine geophysical data showed bedform evidence for former ice stream flows toward the shelf edge at the LGM (Wellner et al., 2001; Lowe and Anderson, 2002; Evans et al., 2006; Larter et al., 2009). In the eastern ASE, Lowe and Anderson (2002, 2003) distinguished a series of discrete geomorphic zones along one particular palaeo- ice stream track. Importantly, these and other data have been used to develop a model of bedform variability under Antarctic palaeoice streams (Wellner et al., 2001), whereby small features eroded into bedrock progressively evolve downflow into more elongate sedimentary bedforms. In this model, and in similar studies of ice stream landsystems (Wellner et al., 2001, 2006; Mosola and Anderson, 2006; Bradwell et al., 2008; Ottesen et al., 2008), changes in subglacial lithology were proposed as the main control on ice dynamics, and hence on the along-flow geomorphic progression. However despite conceptual advances associated with such models, the majority of Antarctic studies used only limited swath bathymetric coverage and often simplified observations as single 'snapshots' in time, impeding more detailed geomorphic interpretations of entire palaeo-ice stream systems.

In this paper, we conduct a detailed and systematic mapping of an Antarctic palaeo-ice stream bed, using a newly acquired and extensive (9950 $\mathrm{km}^{2}$ area) marine geophysical dataset. Many studies of northern hemisphere palaeo-ice sheets adopt a rigorous mapping approach for dividing the temporal and spatial relationships of glacial landforms (Stokes and Clark, 2003a; Stokes et al., 2009). While many of these have recognised complex patterns of flow related to palaeo-ice streams (Clark, 1997), Antarctic case-studies have not followed suite, and the local complexity of subglacial conditions hinted at by recent studies on modern ice stream beds (King et al., 2007, 2009; Smith and Murray, 2009) has not been replicated for Antarctic palaeo-ice stream beds thus far. We map subglacial bedforms with aims to: (i) characterise the geomorphology of the western ASE continental shelf; (ii) reconstruct the LGM flow pattern of this sector of the 
WAIS; and (iii) propose a revised model for the generation of bedforms by ice streams on the shelf, in which we focus on temporal and substrate controls, and implications for ice sheet dynamics.

\section{Previous work in the Amundsen Sea Embayment}

The ASE currently drains approximately $25 \%$ of the area of the WAIS (Fig. 1). The shelf break in the region lies $\sim 200-480$ $\mathrm{km}$ from the modern ice front. Despite recent focus on the activity of glaciers in the embayment, the glacial history of the ASE, since the LGM, is not well constrained. Previous studies on LGM ice sheet extent in the eastern ASE provided geomorphological evidence that a palaeo-ice stream extended from Pine Island Bay at least as far as the middle continental shelf and possibly to the shelf edge (Lowe and Anderson, 2002, 2003). Evans et al. (2006) favoured the latter interpretation based on streamlined bedforms observed in an outer shelf trough to the northwest of the main Pine Island trough (Fig. 1). West of Pine Island Bay, offshore from the Getz Ice Shelf, Wellner et al. (2001) reported further evidence of former ice grounding on the continental shelf and a pronounced downflow change in glacial bedforms, coincident with the transition from acoustic basement (probably crystalline bedrock) on the inner shelf, to seaward dipping, erosionally-truncated Cenozoic sedimentary strata overlying acoustic basement on the middle shelf (Fig. 1, tie point 1; Table 1). Wellner et al. (2001) also showed that this was a common scenario for many palaeo-ice streams around West Antarctica, and inferred that substrate conditions had a major influence upon ice stream establishment, bed morphology and flow at the LGM. Recently, Larter et al. (2009) presented an overview of new multibeam bathymetry data from the western ASE, showing that there was an extensive LGM ice stream characterised by a complex arrangement of subglacial bedforms along its track. While the authors suggested a strong relationship between basal conditions and substrate for this ice stream, no new constraints on substrate type and only limited detail have been presented on the landform signature to-date.

\section{Data and methods}

Marine geophysical and geological data for this study were collected on cruises JR141 of the RRS James Clark Ross (JCR) and ANT-XXIII/4 of the RV Polarstern (PS) in 2006 (Gohl, 2007; Larter et al., 2007). Bathymetric data were collected using hull-mounted Kongsberg EM120 and Atlas Hydrosweep DS-2 multibeam swath systems (Figs. 1 and 2). The EM120 system emits 191 beams with frequencies between 11.25 and $12.75 \mathrm{kHz}$ and the DS-2 system emits 59 beams at $15.5 \mathrm{kHz}$. For the EM120, maximum practical port and starboard beam angles are $68^{\circ}$, giving a swath width of c. $2-8 \mathrm{~km}(\sim 5 \times$ water depth). Beam raypaths and sea-floor depths were calculated in near-real time using sound velocity profiles derived from conductivity-temperature-depth casts on the same cruises. Swath data were processed in MB-System (Caress and Chayes, 2003) to remove anomalous depth values, and gridded at 30 and $50 \mathrm{~m}$ cell sizes (resolution roughly equivalent to a Landsat $\mathrm{ETM}+$ image). Bedforms were digitised from swath bathymetry grids in ArcGIS 9.

Parametric sub-bottom echo sounder profiles were collected simultaneously with the swath bathymetry, using a Kongsberg TOPAS system ('burst' pulse at secondary frequency of $2.8 \mathrm{kHz}$ ) on $J C R$ and an Atlas PARASOUND system ('chirp' pulse with secondary frequency $2.5-5.5 \mathrm{kHz}$ ) on PS. TOPAS and PARASOUND profiles image the sea floor and sub-surface at a high resolution (up to about $1 \mathrm{~m}$ vertically), to as much as $\sim 50 \mathrm{~m}$ below sea floor (see supplementary material in Larter et al., 2009). Sediment coring was also undertaken to obtain detailed information about the nature of the sea-floor sediments (see Larter et al., 2007; Smith et al., 2009 and Hillenbrand et al., in press). Core data and photographs are available from the PANGAEA world data center at http://doi. pangaea.de/10.1594/PANGAEA.724192.

Single-channel seismic reflection data were also acquired on cruise JR141. The source consisted of a cluster array of $4 \times 0.661$ Bolt 600B airguns with wave shape kits, towed at a depth of $1.5 \mathrm{~m}$. A Services et Instruments de Geophysique hydrophone streamer with a single, $32 \mathrm{~m}$ long active section was used and data were recorded on a British Geological Survey/CODA acquisition system. Additional multichannel seismic lines were acquired on the shelf by PS (see Uenzelmann-Neben et al., 2007; Gohl, 2007; Weigelt et al., in press). Two JCR seismic reflection profiles and four PS profiles were used to evaluate sub-surface geology in the western ASE (Fig. 1) (Larter et al., 2007).

Surface roughness measurements were derived from the $50-\mathrm{m}$ swath grid, using native tools in ArcGIS 9. Roughness was calculated by measuring the standard deviation of the variation in grid values within a moving neighbourhood window of $n \times n$ cells (after Rippin et al., 2006). Three separate analyses, using windows of $3 \times 3$, $20 \times 20$ and $100 \times 100$ grid cells, captured roughness at short $(150 \mathrm{~m})$, medium $(1 \mathrm{~km})$ and long $(5 \mathrm{~km})$ scales (Siegert et al., 2004).

\section{Bathymetry and substrate}

\subsection{Bathymetric character}

New swath bathymetric data reveal the detailed sea-floor character of the western ASE shelf (Fig. 2). The inner shelf is dissected by three tributary troughs with associated basins directly in front of the Dotson-Getz ice shelves (Fig. 2). The basins are 18-40 $\mathrm{km}$ wide and 1100-1600 m deep. Each of the rugged, steep-sided troughs is u-shaped in cross-profile and has a long-axis that shoals seaward (Fig. S1). The three troughs converge northwards to form a single large trough (Figs. 2 and S1), which extends on an arcuate NW heading over a distance of $>250 \mathrm{~km}$ towards the shelf break (Figs. 1 and 2). The width of the trough on the middle shelf is $\sim 65$

Table 1

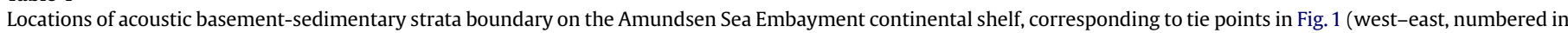
order from 1 to 5 ).

\begin{tabular}{|c|c|c|c|}
\hline Longitude & Latitude & Line No. (data type) & Reference \\
\hline$-115^{\circ} 18^{\prime} \mathrm{W}$ & $-73^{\circ} 30.798^{\prime} S$ & NBP 9902-10 (MCS) & (1) Wellner et al., 2001 \\
\hline$-115^{\circ} 10.68^{\prime} \mathrm{W}$ & $-73^{\circ} 28.782^{\prime} S$ & BAS 056-S111 (SCS) & (2) This study \\
\hline$-110^{\circ} 45^{\prime} \mathrm{W}$ & $-73^{\circ} 55.944^{\prime} \mathrm{S}$ & AWI 2006-0005 (MCS) & (3) Weigelt et al., in press \\
\hline$-107^{\circ} 21.18^{\prime} \mathrm{W}$ & $-73^{\circ} 24^{\prime} \mathrm{S}$ & NBP 99/02 (SCS) & (4) Lowe and Anderson, 2002 \\
\hline$-103^{\circ} 48^{\prime} \mathrm{W}$ & $-72^{\circ} 35^{\prime} \mathrm{S}$ & AWI 2006-0011 (MCS) & (5) Uenzelmann-Neben et al., 2007 \\
\hline
\end{tabular}

SCS, single-channel seismic; MCS, multichannel seismic. 

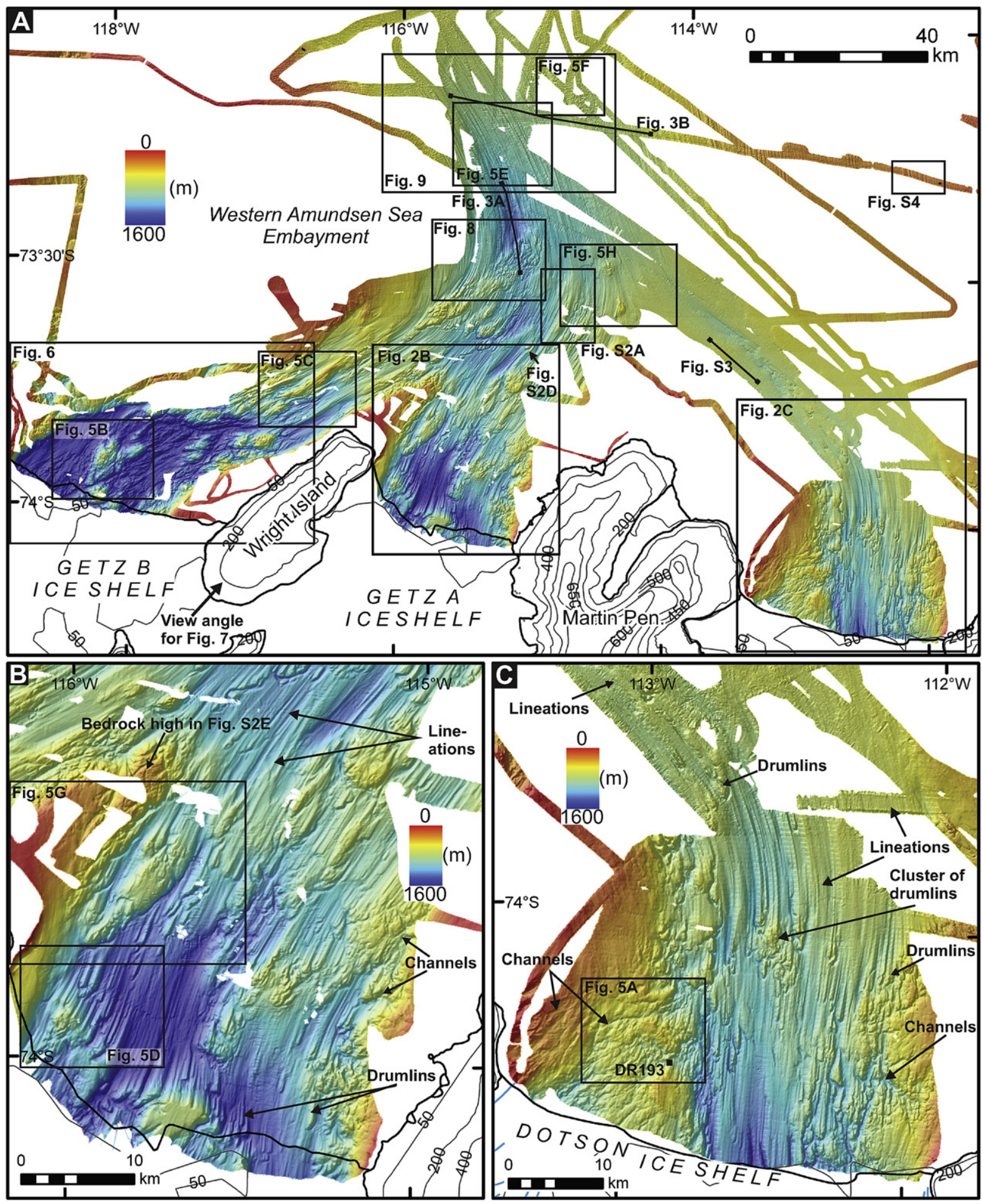

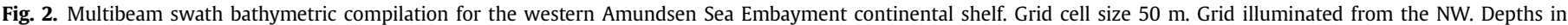

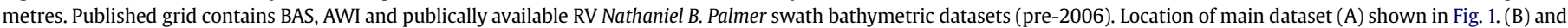
(C) show detail of the inner shelf basins.

km (Fig. S1), and its floor gradually diminishes in amplitude away from the coast (Nitsche et al., 2007).

\subsection{Substrate}

Substrate types within the trough were investigated by seismic profiling. Single-channel seismic (SCS) line BAS056-S111 was collected north-south along the trough axis (location Figs. 1 and 2). Two distinct seismic facies are observed:

(1) Opaque acoustic basement with chaotic reflectors of varying frequency and amplitude characterises most of the inner shelf (Fig. 3A, and inset panel). We interpret the facies as crystalline bedrock, or deformed sedimentary rocks, based on its seismic 
character (Wellner et al., 2001; Gohl, 2007). A dredge sample (DR193) collected directly north of the Dotson Ice Shelf, and rock samples obtained from the northern coast of Wright Island (Gohl, 2007) retrieved granite and granodiorites, respectively, lending support to our 'crystalline bedrock' substrate interpretation. Any sedimentary cover overlying the acoustic basement is absent or thin. However, soft diamictons (soft tills) overlain by postglacial gravels and muds are known to form local drapes several metres thick on the inner shelf (Smith et al., 2009), but these are rarely resolved on our seismic reflection data (due to resolution), or sub-bottom profiles (due to signal attenuation).

(2) On the middle shelf further north, gently northwestwarddipping high-amplitude reflections, overlie and onlap onto the acoustic basement (Fig. 3A), forming a second facies whose acoustic character is typical of interbedded glacigenic diamictons, marine muds and sands (Stoker et al., 1997). We interpret this facies as indurated to unlithified sedimentary strata (cf. Nitsche et al., 2000; Wellner et al., 2006). The strata thicken towards the shelf break, eventually exceeding $1 \mathrm{~km}$ thickness (Fig. 3A), based on mean velocities above $2000 \mathrm{~ms}^{-1}$ (Gohl et al., 2007). Within the uppermost $100 \mathrm{~m}$ below the sea floor, the seaward dipping sediments are truncated by a regional unconformity that crops out in the mid-shelf area (Fig. 3A). The transition from acoustic basement to sedimentary substratum occurs at $73^{\circ} 28.2^{\prime} \mathrm{S}$ on the northward transect (Table 1 ).

No seismic profiles have been collected further north along the western ASE trough. However, Lowe and Anderson (2002) and Uenzelmann-Neben et al. (2007) published seismic profiles from the eastern ASE, which show northward-dipping strata continuing beneath the outer shelf, where they are unconformably overlain by more gently dipping to flat-lying strata that continue to the shelf edge. These relatively flat-lying strata covering the outer shelf have probably accumulated during the period over which the ice sheet grounding line has periodically advanced across the continental shelf. (Larter et al., 1997; Nitsche et al., 2000; Lowe and Anderson, 2002).

Line BAS056-S109 was collected east-west across the trough, oblique to its long-axis (Fig. 3B; location, Fig. 2). The profile shows layered, dipping strata younging consistently in a (north-) westward direction (Fig. 3B). The acoustic character indicates a sedimentary substrate across the trough, although it varies within the succession below the regional unconformity (Fig. 3B). In conjunction with observations from previously published data, these new profiles enabled us to map the boundary between crystalline bedrock and/or deformed sedimentary rocks (herein referred to simply as 'bedrock') on the inner shelf and sedimentary strata on the middle to outer shelf in the ASE (Fig. 1; Table 1).

\subsection{Sea-floor roughness}

To provide further information on substrate properties, we analysed the bed roughness of the western ASE shelf, which may be an important control on the basal mechanics of ice streams (e.g. Rippin et al., 2006). The sea floor is organised into two coherent geographic areas, with specific roughness attributes (Fig. 4): (1) the inner shelf corresponds to areas with generally high roughness values and high variability. This roughness occurs at all scales, and is consistent with our interpretation that the inner shelf sea floor is composed of bedrock and/or deformed sedimentary rock; (2) in contrast, areas of the middle to outer shelf underlain by dipping strata are characterised by remarkably uniform and low roughness, as expected for indurated or soft-sediments. Thus the most dramatic change in sea-floor roughness occurs at the boundary between bedrock and sedimentary strata.

\section{Geomorphology: description and interpretation of bedforms}

Highly varied glacial geomorphological features occur across the shelf (Figs. 2 and 5). We divide their description here into: (i) the inner shelf; (ii) the mid-shelf, where tributary troughs converge; and (iii) the middle and outer shelf north of $73^{\circ} 30^{\prime} \mathrm{S}$. All features are interpreted as subglacial or ice marginal (after Ottesen et al., 2008), and adhere to the criteria defined in Table 2.

\subsection{Inner shelf}

\subsubsection{Getz B trough}

The Getz B trough inner shelf ( $<1600 \mathrm{~m}$ water depth) is characterised by a distinctive channelised, erosional topography (Fig. 6A). Large-scale valleys are incised into acoustic basement: the most prominent of these measuring $\sim 25 \mathrm{~km}$ long, up to $4.5 \mathrm{~km}$ wide, and 150-450 m deep (Table 2). The valleys have an undulating thalweg, an intermediate $\mathrm{u}$-to-v-shaped cross-profile, and abrupt initiation and termination points (Figs. 6B,C). We interpret these features as tunnel valleys formed beneath an ice sheet or icesheet margin during multiple subglacial meltwater discharge events, or modified by constant, steady-state meltwater erosion over successive glacial phases (Ó Cofaigh, 1996; Lowe and Anderson, 2003; Lonergan et al., 2006; Smith et al., 2009).

Smaller, morphologically-similar channels connect to the tunnel valleys, and form an anastomosing pattern, which evolves from a broad network near the present-day ice shelf front into two major outlets downstream (Fig. 6). Smaller channels are sinuous (Fig. 6; Table 2), while larger channels are straighter, possibly following structural trends in the bedrock (Anderson and Oakes-Fretwell, 2008). Like the valleys, we interpret the channels as a result of subglacial meltwater erosion based on their characteristic geometry, termination and initiation points, uneven thalweg, and size (Fig. 5A) (cf. Lewis et al., 2006).

The few streamlined bedforms imaged in this area comprise irregular 'gouged' acoustic basement on surrounding highs (Figs. 5B and 6) and lenticular, subtly streamlined ridges with high-amplitudes (70-200 m; lengths $\sim 1000-5000 \mathrm{~m}$ ) that intervene larger valleys (Fig. 6). We interpret these landforms as 'whalebacks' formed at the base of an ice sheet.

Downstream, the channelised topography gives way abruptly to attenuated lineations (Figs. 6 and 7). The lineations are formed within a substrate, which we have interpreted as bedrock based on its acoustic character. Alternatively, the lineations may be formed in thin layers of sediment (such as stiffer tills) that overly the bedrock, but that are not resolved on our acoustic profiles. At $1-20 \mathrm{~km}$ in length, $\sim 100-500 \mathrm{~m}$ in width, and up to $50 \mathrm{~m}$ relief, lineations are highly elongated in this zone, with ratios of $>45: 1$ (Fig. 5C). Shorter streamlined oval-shaped and lobate hills, interpreted as drumlins (e.g., Clark et al., 2009), occasionally intersperse the lineations. Both the drumlins and lineations are interpreted as subglacial bedforms. Meltwater channels are observed around the base of bed protrusions, drumlin heads and sea-floor highs (Figs. 6 and 7).

\subsubsection{Getz A trough}

The central of the three tributary basins ( $~ 1100$ m deep; Fig. 2B) is characterised by irregular and high-relief topography on which a range of bedforms are superimposed (Fig. 7). Streamlined glacial lineations are common in the basin (Figs. 5G,H and 7) with lengths of 1-15 km, widths $100-400 \mathrm{~m}$, a relief of $10-100 \mathrm{~m}$ and length: width ratios from 5:1 to $70: 1$. Clusters of drumlins intersperse the lineations and occur in a range of sizes, from small ovoid to large attenuated forms. The drumlins are $0.2-16 \mathrm{~km}$ long, 66-662 m wide, $10-150 \mathrm{~m}$ high (many $\sim 60 \mathrm{~m}$ at their heads), and have 
A Drumlins $\longrightarrow$ Mega-scale glacial lineations

Along flow profile

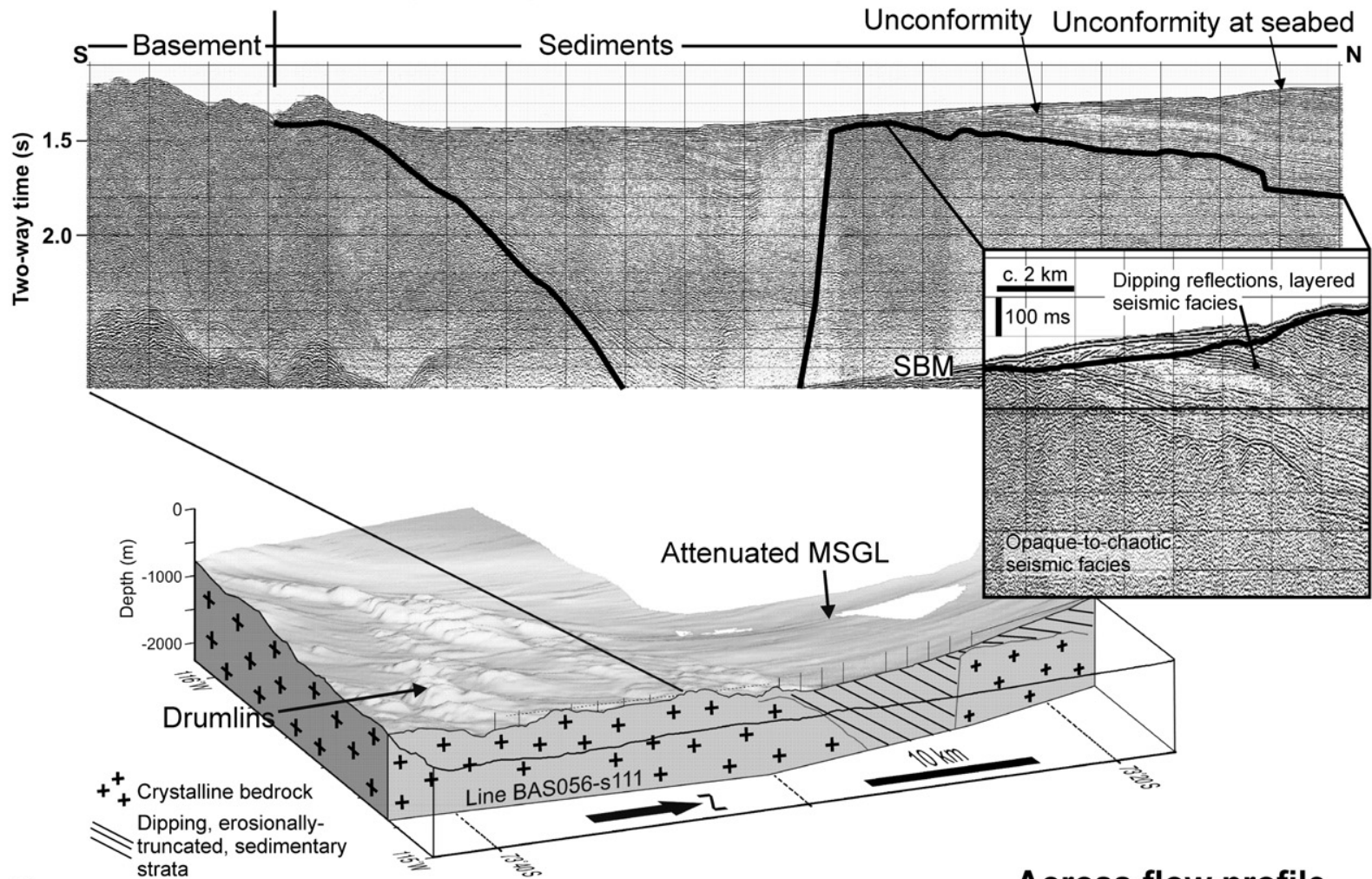

B strata

Trace No.

Across flow profile
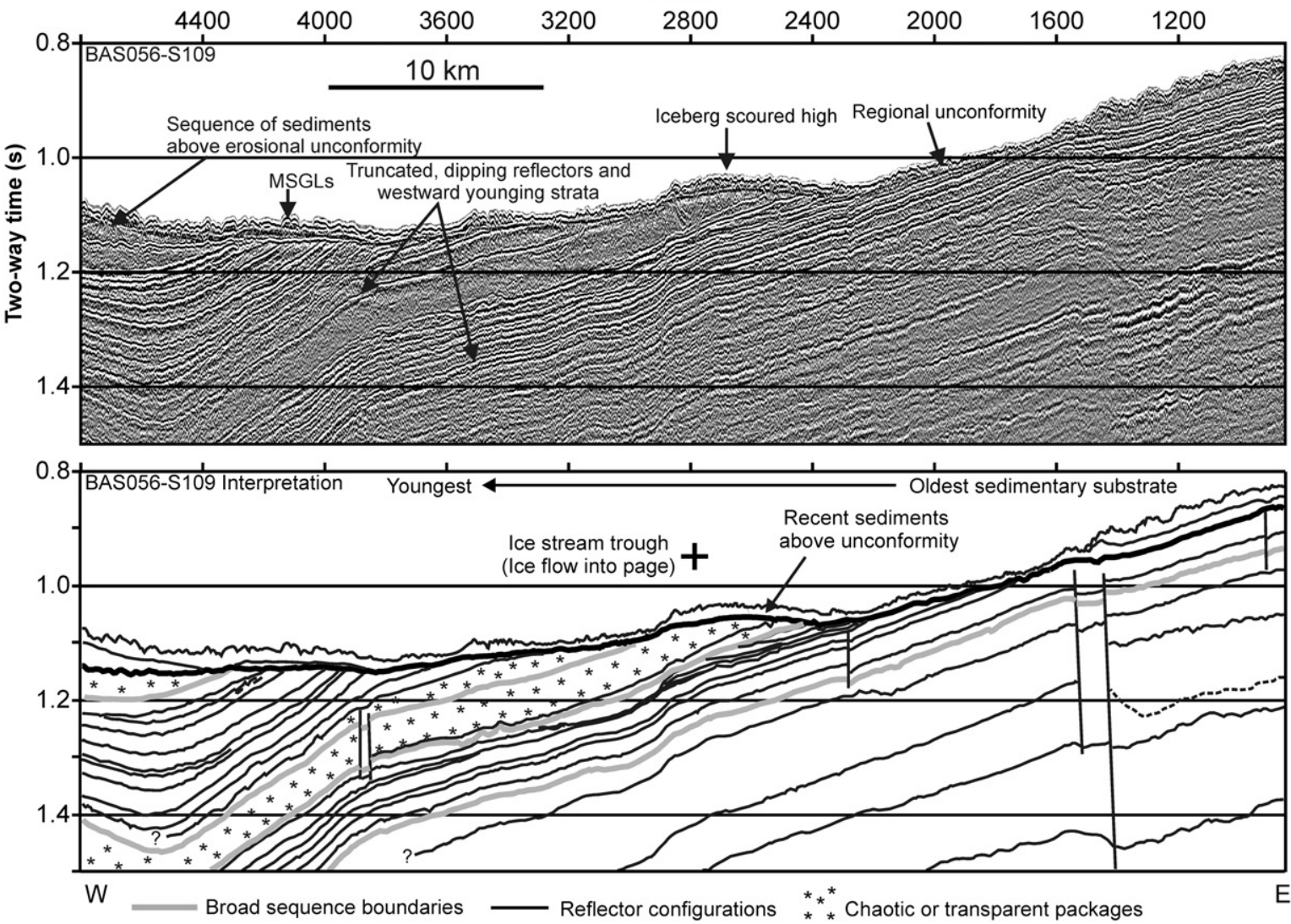

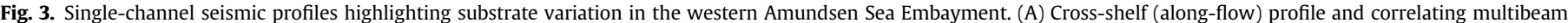

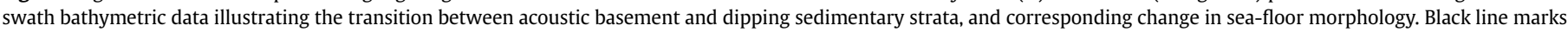

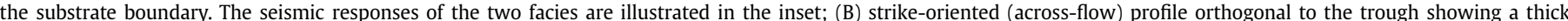

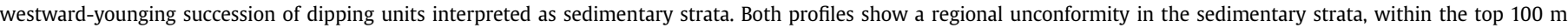
below seabed. Locations of the full profiles are shown in Fig. 1, and profile excerpts are located on Fig. 2. SBM, sea bed multiple. 

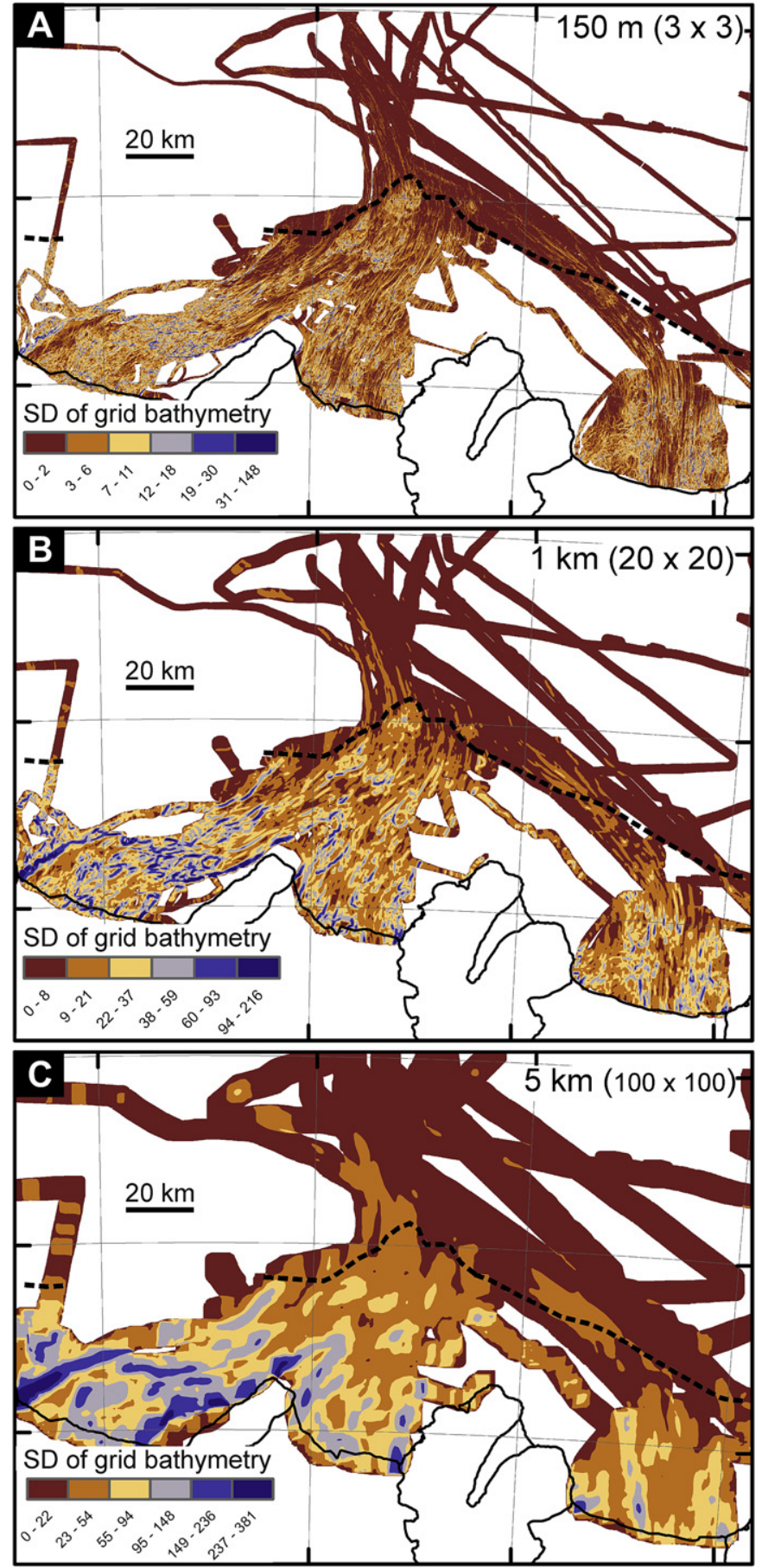

Fig. 4. Maps of bed roughness in the western Amundsen Sea Embayment, analysed from the swath bathymetric grid. Standard deviation (SD) of the $50-\mathrm{m}$ bathymetry grid calculated for: (A) each $5 \times 5$ cell region; (B) each $20 \times 20$ cell region; and (C) each $100 \times 100$ cell region. Note the high roughness inner shelf and the remarkably smooth middle shelf.

elongation ratios from $\sim 1.5: 1$ to $84: 1$ (mean 13:1). Sub-bottom profiles through drumlins reveal uniform acoustic transparency suggesting that they may be formed in bedrock or a thin, high acoustic impedance sediment layer (such as stiff till). Frequently, crescentic overdeepenings occur around drumlin heads (Figs. 5D and S2) and locally feed into streamlined grooves located alongside of drumlin tails. Such overdeepenings likely result from pressure melting, focussed glacial scouring, or meltwater erosion at the heads of glacial landforms (Lowe and Anderson, 2002; Wellner et al., 2006).
Large, isolated bedrock highs, 100's of metres high, also occur throughout the central spine of the Getz A basin (e.g., Figs. 5G and 7). Some are capped by small drumlins, lineations, or meltwater channels. Meltwater channels or glacially-scoured overdeepenings at the upstream face of bedrock highs are commonly aligned oblique or transverse to streamlined bedforms. Channels also characterise the flanks of the basin (Fig. 7).

\subsubsection{Dotson trough}

A complex set of bedforms, including highly elongated lineations and drumlins, characterises the basin floor in front of the Dotson Ice Shelf (Fig. 2C). Near the ice front, short drumlins and glacial grooves intermingle with longer attenuated drumlins. However, only $\sim 20 \mathrm{~km}$ from the ice front, a distinct cluster of drumlins occurs, progressing into highly elongated glacial lineations to the north (Fig. 2C). Anastomosing channel networks are incised between bedforms on the shallower flanks of the basin, and intersperse short drumlins and lineations (Fig. 5A).

\subsection{Inner to middle shelf}

The three tributaries converge into one large trough at $\sim 73^{\circ} 30^{\prime}$ $\mathrm{S}$ (Fig. 7). A bedform continuum is visible locally at the convergence between the Getz A and B tributaries (Figs. 2B and S2E), where small ( $<500 \mathrm{~m}$ long) drumlins on top of the inter-trough bedrock high pass progressively downstream into more elongate crag-andtails, drumlins and lineations over a distance of only a few kilometres (Fig. S2F).

Chains of streamlined bedrock ridges and highs characterise the convergence zones of the trough tributaries (Figs. $5 \mathrm{H}$ and 7). Bedrock ridges with 'crag-and-tails' are moulded in a NW-NE direction, parallel to other streamlined bedforms (e.g., Fig. 5H; cf. Fig 5 in Clark et al., 2009). Several of the larger bedrock ridges have a drumlinoid expression (Fig. S2), with some likely seeded from bedrock outcrops (e.g. Fig. S2D), while others form discrete summits (Fig. 7). Some highs ( $\leq 200 \mathrm{~m}$ high) are interspersed by swarms of drumlins and lineations that are shallower in relief (10$60 \mathrm{~m}$ high). Other highs, however, are topped by lineations with orientations different from surrounding bedforms, suggesting the co-occurrence of multiple generations of bedforms. Downflow of the Getz A-Getz B convergence zone, drumlins of variable length intermingle with lineations with elongation ratios from $<10: 1$ to $>60: 1$ (Fig. 7). West-east bands of high-relief summits characterise the broad morphology and are surrounded by meltwater channels interspersing a variety of bedforms of different shapes and sizes.

The furthest downstream drumlins in the trough terminate at the boundary between different substrate types (Fig. 8). Their lobate heads are relatively small ( $\leq 60 \mathrm{~m}$ relief) and many develop downstream into highly elongated, parallel lineations. However several drumlins are notably short with low elongation ratios. One of the larger drumlins is imaged in line BAS056-S111 (Fig. 8B), where its base and a well-defined tail can be observed. The drumlin surface is highly reflective and its internal structure is acousticallytransparent, which suggests that this feature is a 'true' drumlin consisting of homogenous, unstratified and relatively high acoustic impedance sediments, such as till (Smith et al., 2007). These observations are consistent with some drumlins being products of natural, internal ice flow instability at the bed of fast or accelerating overriding ice (Boulton and Hindmarsh, 1987; Clark et al., 2009). Interweaving meltwater channels and isolated zones of smooth, featureless sea floor are observed between the drumlins (marked with 'X's on Fig. 8A).

Distinct landforms, which are wedge-shaped on profiles and orientated parallel to the elongation of bedforms, occur in the middle of the trough on the inner shelf and approximately $80 \mathrm{~km}$ 

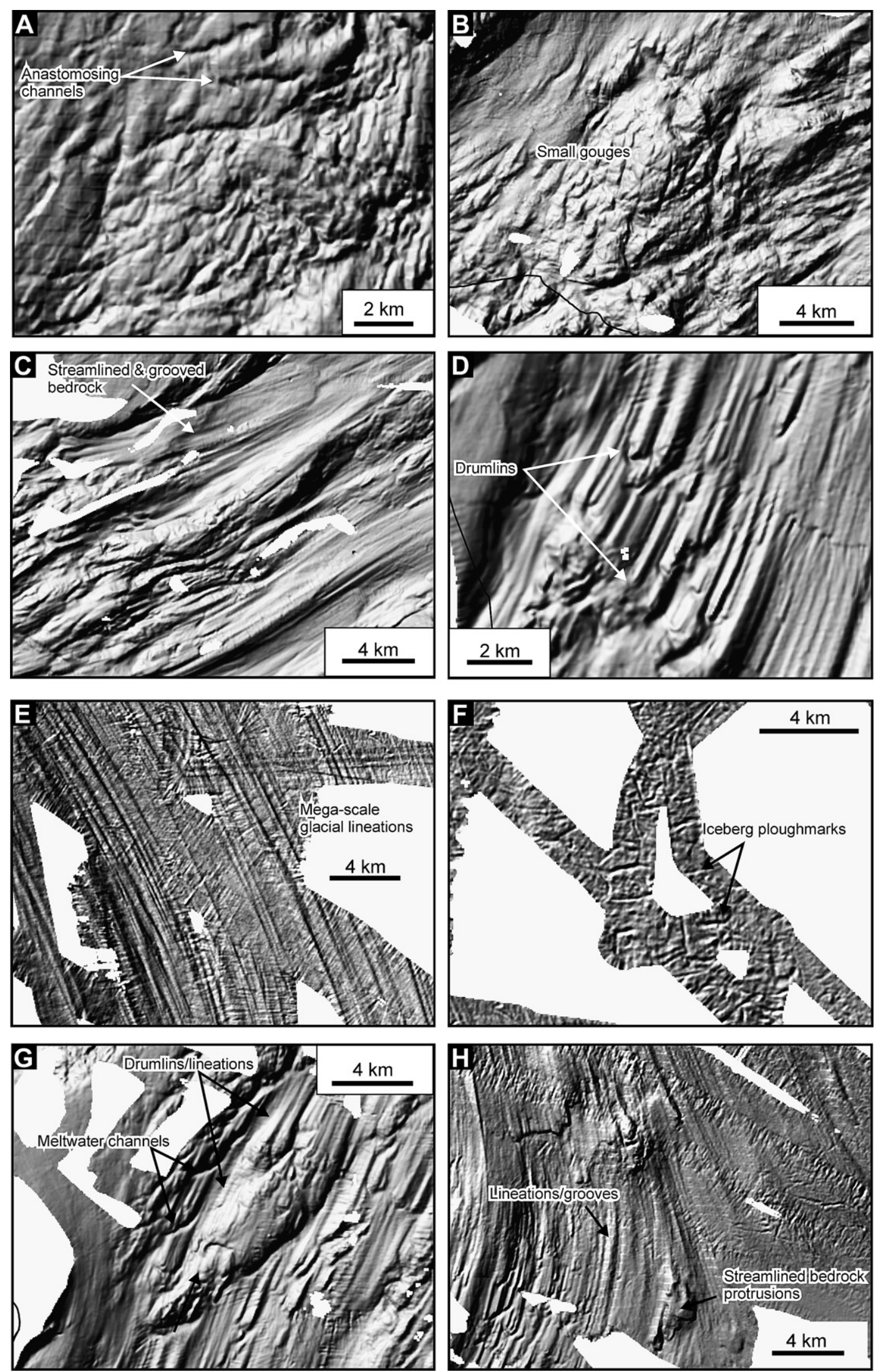

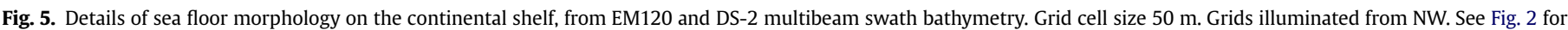
locations. 
Table 2

Morphology and classification of glacial landforms observed on the continental shelf in the western Amundsen Sea Embayment.

\begin{tabular}{|c|c|c|c|c|c|c|c|}
\hline $\begin{array}{l}\text { Descriptive } \\
\text { term }\end{array}$ & $\begin{array}{l}\text { Landform } \\
\text { interpretation }\end{array}$ & Defining characteristics & $\begin{array}{l}\text { Geometry Min (Max) } \\
\text { L-W-H }\end{array}$ & $\begin{array}{l}\text { Formational } \\
\text { process }\end{array}$ & Example (citation) & $\begin{array}{l}\text { Example } \\
\text { (this study) }\end{array}$ & $\begin{array}{l}\text { GIS mapping } \\
\text { class (see } \\
\text { Fig. 11) }\end{array}$ \\
\hline $\begin{array}{l}\text { Streamlined } \\
\text { bedforms } \\
\text { (ridge/ } \\
\text { groove sets) }\end{array}$ & $\begin{array}{l}\text { Mega-scale } \\
\text { glacial } \\
\text { lineations } \\
\text { (MSGL) }\end{array}$ & $\begin{array}{l}>10: 1 \text { elongation, parallel } \\
\text { bedform sets, groove-ridges in } \\
\text { upper transparent acoustic unit, } \\
\text { low-to-intermediate shear } \\
\text { strength diamicton in core } \\
\text { record }\end{array}$ & $\begin{array}{l}6 \mathrm{~km}-131 \mathrm{~m}-2 \mathrm{~m} \\
(38 \mathrm{~km}-451 \mathrm{~m}-18 \mathrm{~m})\end{array}$ & $\begin{array}{l}\text { Groove- } \\
\text { ploughing } \\
\text { (depositional/ } \\
\text { erosional; in till) }\end{array}$ & $\begin{array}{l}\text { Marguerite Trough } \\
\text { ice stream (Ó } \\
\text { Cofaigh et al., 2002) }\end{array}$ & $\begin{array}{l}\text { Figs. } 2 \mathrm{~A} \text { and } 9, \\
\text { middle shelf on } \\
\text { sediments }\end{array}$ & $\begin{array}{l}\text { Streamlined } \\
\text { bedform (ridge/ } \\
\text { groove) }\end{array}$ \\
\hline “ & $\begin{array}{l}\text { Bedrock } \\
\text { lineation }\end{array}$ & $\begin{array}{l}\text { Elongate ridge/grooves, formed } \\
\text { in or on acoustic basement }\end{array}$ & $\begin{array}{l}1 \mathrm{~km}-100 \mathrm{~m}-10 \mathrm{~m} \\
(15 \mathrm{~km}-400 \mathrm{~m}-100 \mathrm{~m})\end{array}$ & $\begin{array}{l}\text { Erosional } \\
\text { (bedrock) }\end{array}$ & $\begin{array}{l}\text { Northern Norway } \\
\text { (Ottesen et al., } \\
\text { 2008) }\end{array}$ & Fig. 5C, inner shelf & $\begin{array}{l}\text { Streamlined } \\
\text { bedform (ridge/ } \\
\text { groove) }\end{array}$ \\
\hline “ & Drumlin & $\begin{array}{l}\text { Short to attenuated, lobate/ } \\
\text { teardrop-shaped head, with/ } \\
\text { without tail, overdeepening } \\
\text { around heads and between } \\
\text { features. Sometimes seeded } \\
\text { head }\end{array}$ & $\begin{array}{l}2 \mathrm{~km}-66 \mathrm{~m}-10 \mathrm{~m} \\
(16 \mathrm{~km}-662 \mathrm{~m}-150 \mathrm{~m})\end{array}$ & $\begin{array}{l}\text { Depositional/ } \\
\text { erosional or both } \\
\text { (till and/or } \\
\text { bedrock) }\end{array}$ & $\begin{array}{l}\text { Antarctic Peninsula } \\
\text { (Canals et al., 2002) }\end{array}$ & $\begin{array}{l}\text { Figs. 5D and S2D, } \\
\text { Getz A tributary }\end{array}$ & Drumlin \\
\hline $\begin{array}{l}\text { Streamlined } \\
\text { bedrock } \\
\text { ridge/high }\end{array}$ & $\begin{array}{l}\text { Crag-and-tail } \\
\text { (drumlin } \\
\text { appearance) }\end{array}$ & $\begin{array}{l}\text { Large bedrock head or } \\
\text { protrusion with tail in } \\
\text { downslope direction of ice flow. } \\
\text { Cruder form than drumlin. } \\
\text { Till or bedrock composition }\end{array}$ & As above & $\begin{array}{l}\text { Depositional/ } \\
\text { erosional or both } \\
\text { (till and/or } \\
\text { bedrock) }\end{array}$ & $\begin{array}{l}\text { Varangerfjorden, } \\
\text { northern Norway } \\
\text { (Ottesen et al., } \\
\text { 2008) }\end{array}$ & $\begin{array}{l}\text { Fig. } 5 \mathrm{H} \text {, Dotson- } \\
\text { Getz A convergence }\end{array}$ & $\begin{array}{l}\text { Drumlin } \\
\text { (where } \\
\text { mapped) }\end{array}$ \\
\hline “ & Whaleback & $\begin{array}{l}\text { Lenticular, symmetric, } \\
\text { streamlined form, formed in } \\
\text { bedrock (acoustic basement), } \\
\text { smooth morphology }\end{array}$ & $\begin{array}{l}1 \mathrm{~km}-500 \mathrm{~m}-70 \mathrm{~m} \\
(5 \mathrm{~km}-500 \mathrm{~m}-200 \mathrm{~m})\end{array}$ & $\begin{array}{l}\text { Erosional } \\
\text { (bedrock) }\end{array}$ & $\begin{array}{l}\text { NW Scotland } \\
\text { (Bradwell et al., } \\
\text { 2008) }\end{array}$ & $\begin{array}{l}\text { Fig. } 6 \text {, Getz B } \\
\text { tributary }\end{array}$ & $\begin{array}{l}\text { Not mapped } \\
\text { (only a few) }\end{array}$ \\
\hline $\begin{array}{l}\text { Curvilinear } \\
\text { scours }\end{array}$ & $\begin{array}{l}\text { Iceberg } \\
\text { ploughmark }\end{array}$ & $\begin{array}{l}\text { Straight to sinuous furrows, } \\
\text { hooked tails, uniform scour } \\
\text { depths, cross-cutting, random } \\
\text { orientations }\end{array}$ & $\begin{array}{l}100 \mathrm{~m}-100 \mathrm{~m}-4 \mathrm{~m} \\
(5 \mathrm{~km}-250 \mathrm{~m}-10 \mathrm{~m})\end{array}$ & $\begin{array}{l}\text { Erosional (some } \\
\text { depositional; in } \\
\text { till) }\end{array}$ & $\begin{array}{l}\text { Antarctic Peninsula } \\
\text { (Pudsey et al., 1994) }\end{array}$ & Fig. 9, middle shelf & $\begin{array}{l}\text { Iceberg } \\
\text { ploughmarks }\end{array}$ \\
\hline $\begin{array}{l}\text { Sea-floor } \\
\text { wedges }\end{array}$ & $\begin{array}{l}\text { Grounding } \\
\text { zone wedge }\end{array}$ & $\begin{array}{l}\text { Steep distal sea-floor ramp, } \\
\text { shallow backslope, wedge } \\
\text { profile, lineations terminate at } \\
\text { wedge crest, lateral ramp } \\
\text { continuity }\end{array}$ & $10 \mathrm{~km}-5 \mathrm{~km}-100 \mathrm{~m}$ & $\begin{array}{l}\text { Deposition at } \\
\text { stable ice margin } \\
\text { (till) }\end{array}$ & $\begin{array}{l}\text { Joides Trough } \\
\text { (Howat and } \\
\text { Domack, 2003). }\end{array}$ & $\begin{array}{l}\text { Fig. S3, Getz A } \\
\text { inner shelf }\end{array}$ & $\begin{array}{l}\text { Grounding line } \\
\text { positions }\end{array}$ \\
\hline Channels & Tunnel valley & $\begin{array}{l}\text { Undulating long-axis thalweg, } \\
\text { U or rectangular-shaped cross- } \\
\text { profile, km-scale, straight } \\
\text { geometry, tailed start and end } \\
\text { points }\end{array}$ & $25 \mathrm{~km}-500 \mathrm{~m}-400 \mathrm{~m}$ & $\begin{array}{l}\text { Erosional (sub-ice } \\
\text { margin, } \\
\text { subglacial; in } \\
\text { bedrock) }\end{array}$ & $\begin{array}{l}\text { Pine Island Bay } \\
\text { (Lowe and } \\
\text { Anderson, 2003) }\end{array}$ & $\begin{array}{l}\text { Fig. } 6 \text {, Getz B } \\
\text { tributary }\end{array}$ & $\begin{array}{l}\text { Meltwater } \\
\text { channels }\end{array}$ \\
\hline “ & $\begin{array}{l}\text { Subglacial } \\
\text { meltwater } \\
\text { channel }\end{array}$ & $\begin{array}{l}\text { Straight to sinuous channels, } \\
\text { abrupt initiation and } \\
\text { termination points, undulating } \\
\text { thalweg, smaller-scale than } \\
\text { tunnel valleys. Formed in } \\
\text { acoustic basement }\end{array}$ & $\begin{array}{l}1 \mathrm{~km}-100 \mathrm{~m}-20 \mathrm{~m} \\
(10 \mathrm{~km}-500 \mathrm{~m}-60 \mathrm{~m})\end{array}$ & $\begin{array}{l}\text { Erosional } \\
\text { (subglacial, in } \\
\text { bedrock) }\end{array}$ & $\begin{array}{l}\text { Marguerite Trough } \\
\text { inner shelf (Ó } \\
\text { Cofaigh et al., 2002) } \\
\text { See also Smith et al. } \\
\text { (2009) }\end{array}$ & $\begin{array}{l}\text { Fig. } 2 \text {, Dotson } \\
\text { tributary }\end{array}$ & $\begin{array}{l}\text { Meltwater } \\
\text { channels }\end{array}$ \\
\hline
\end{tabular}

north of the Dotson Ice Shelf (Fig. S3). The features possess morphological traits of grounding zone wedges (GZWs), including steep downstream-facing ramps, shallow back-slopes, and lineations terminating at wedge crests (Alley et al., 1989; Vanneste and Larter, 1995; Howat and Domack, 2003; Ó Cofaigh et al., 2005b; Evans et al., 2005a, 2006; Anandakrishnan et al., 2007; Ottesen et al., 2008). The GZW crests rise up to $100-120 \mathrm{~m}$ above the surrounding sea floor, are $\leq 4 \mathrm{~km}$ wide, and extend over 5-10 km. In TOPAS profiles, they appear acoustically-transparent with locally discernable bases, suggesting their composition of homogenous sediment rather than bedrock (Fig. S3) (Vanneste and Larter, 1995; O’Brien et al., 1999).

\subsection{Middle to outer shelf}

Highly elongated (25:1-140:1) and parallel ridge and groove sets dominate the sea floor, north of the substrate boundary (Figs. 8 and 9). The ridges and grooves are 6-38 km long, 131-451 m wide, with shallower relief than inner shelf bedforms, at c. 2-18 m (typically 5-10 m). Spacing between ridges measures $80->300 \mathrm{~m}$. The lineations are developed in the top of a 5-30 m-thick acoustically-transparent unit, whose base is characterised by a smooth, undulating sub-bottom reflector and which is restricted to areas of sedimentary substrate only (Fig. 9D). The lineations show a single NNW-SSE trend within the trough, but on shallow banks to the west and east of the trough, discrete sets of $\mathrm{N}-\mathrm{S}$ aligned lineations also occur (Fig. S4).

The high elongation ratios, long lengths, highly parallel arrangement, the tendency for some bedforms to reduce in amplitude and width downflow (Clark et al., 2003), and their association with an acoustically-transparent reflection unit indicate the features are mega-scale glacial lineations (MSGLs; Clark, 1993). Similar extensive and elongated MSGLs have been observed on the beds of palaeo-ice streams on the Antarctic shelf, and ones within the former Laurentide and Fennoscandian ice sheets (e.g. Shipp et al., 1999; Stokes and Clark, 2001; Ó Cofaigh et al., 2002, 2005a, b, 2007; Dowdeswell et al., 2004; Ottesen et al., 2005; Mosola and Anderson, 2006; Graham et al., 2007).

Such MSGLs are usually formed in lithogenic diamicton with intermediate to low shear strength, interpreted as a deformation till. Vibrocore VC428 from the MSGL zone on the middle shelf recovered $3 \mathrm{~m}$ of homogenous diamicton with low-to-intermediate shear strength, underlying thin units of glaciomarine sandy mud and soft, diatomaceous mud (Fig. 9C). The diamicton possesses 


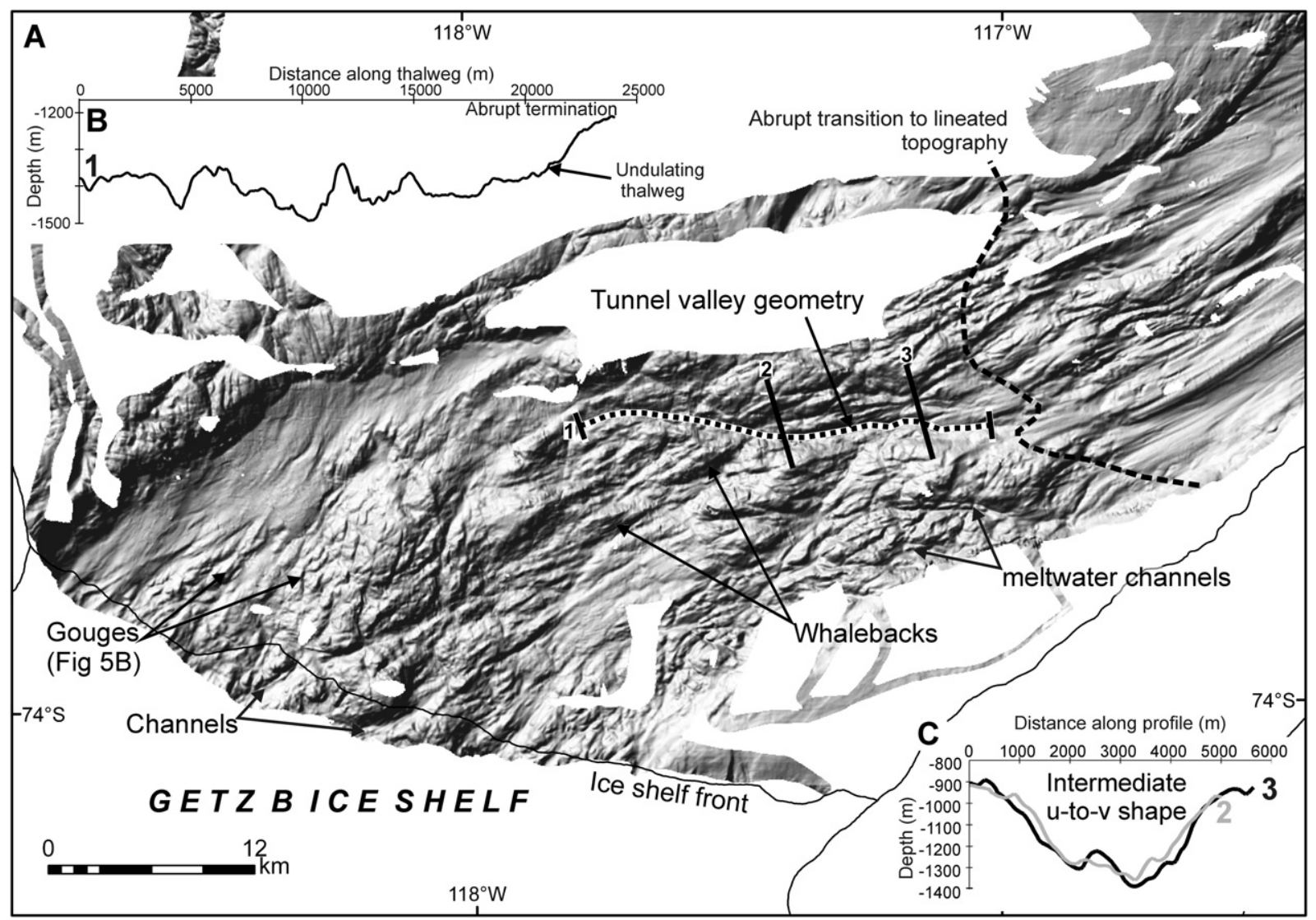

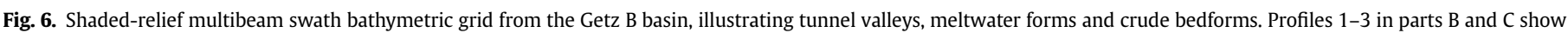

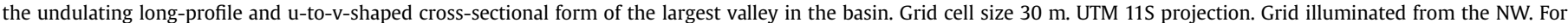
location see Fig. 2.

sedimentological characteristics typical of sub-ice stream deformation till (Anderson, 1999; Ó Cofaigh et al., 2005a, b, 2007; Hillenbrand et al., 2005; Heroy and Anderson, 2005). Thus, based on geomorphic and sedimentary criteria we attribute the formation of MSGLs in the western ASE to fast-flow ice stream activity.

Curvilinear and random-oriented furrows with lengths of 0.2-5 $\mathrm{km}$, widths $<250 \mathrm{~m}$ and uniform depths of $\sim 4-10 \mathrm{~m}$ cross-cut MSGLs on the outer shelf, and occur on shallow banks outside of the trough (e.g., Figs. 5F and 9). In profiles, the features often form a corrugated surface to a distinct transparent acoustic facies interpreted as a till or iceberg turbate (cf. Pudsey et al., 1994; Ó Cofaigh et al., 2002). The furrows arise from iceberg calving and keel-grounding at the seabed and are interpreted as iceberg ploughmarks (after Belderson et al., 1973).

\section{Glacial bedform variability and landsystem interpretation}

\subsection{Bedform progression and elongation}

The subglacial bedforms described above mark the pathway of one or more palaeo-ice streams across the western ASE shelf. The progression of bedforms along-flow reveals clear trends in both type and elongation (Fig. 10). Streamlined lineations, which are found across the entire inner shelf, were eroded into bedrock over sustained periods of ice sheet grounding (Table 2) (Ottesen et al., 2008). Their high elongation indicates formation beneath fastflowing ice, because more than $85 \%$ of them have elongations ratios greater than 10:1 (Fig. 10C) (Stokes and Clark, 2002). The bedforms include whalebacks, which are often associated with periods of former fast-flow (Jansson et al., 2003).
Drumlins and drumlinoid bedforms (including crag-and-tails) also result from fast palaeo-ice flow. They are probably either purely erosional bedrock features or comprise tails of stiff-to-soft till seeded from large bedrock cores. Traditionally, drumlins have been related to deforming bed conditions and ice flow acceleration at substrate boundaries (Wellner et al., 2001), and were mapped in zones of increasing velocity beneath modern Antarctic ice streams (King et al., 2007). The increasing mean elongation ratio of the drumlins in the western ASE documents ice flow acceleration or rapid flow over a large $\sim 70 \mathrm{~km}$ long zone of the inner shelf (Fig. 10D; Table 2), which is consistent with the overall convergent pattern of palaeo-flow indicated by bedform orientations. MSGLs further downstream record full, fast-flowing ice stream activity based on their consistently high elongations (Fig. 10B).

The elongation transect in Fig. 10 demonstrates that mean elongation in all bedforms increases gradually downflow. The boundary between bedrock and sedimentary substrate is notable as a point where the rate in elongations increases downstream (to ratios >90:1) but also where a change in bedform type occurs, from a mixture of streamlined lineations and drumlins upstream to MSGLs downflow (Fig. 10A). Taken together however, it is clear that the bedforms do not record a single continuum of palaeo-ice flow. While the mean downflow increase in elongation is likely to reflect an overall impression of ice flow velocity, the wide range of elongations, and high spatial variations in bedform size and shape on the inner shelf, suggest bedform morphometry has been modulated by additional non-uniform factors. These might comprise small-scale variations in basal conditions related to local substrate, meltwater, local topography and rock outcrops, as well as changing ice flow conditions with time. 


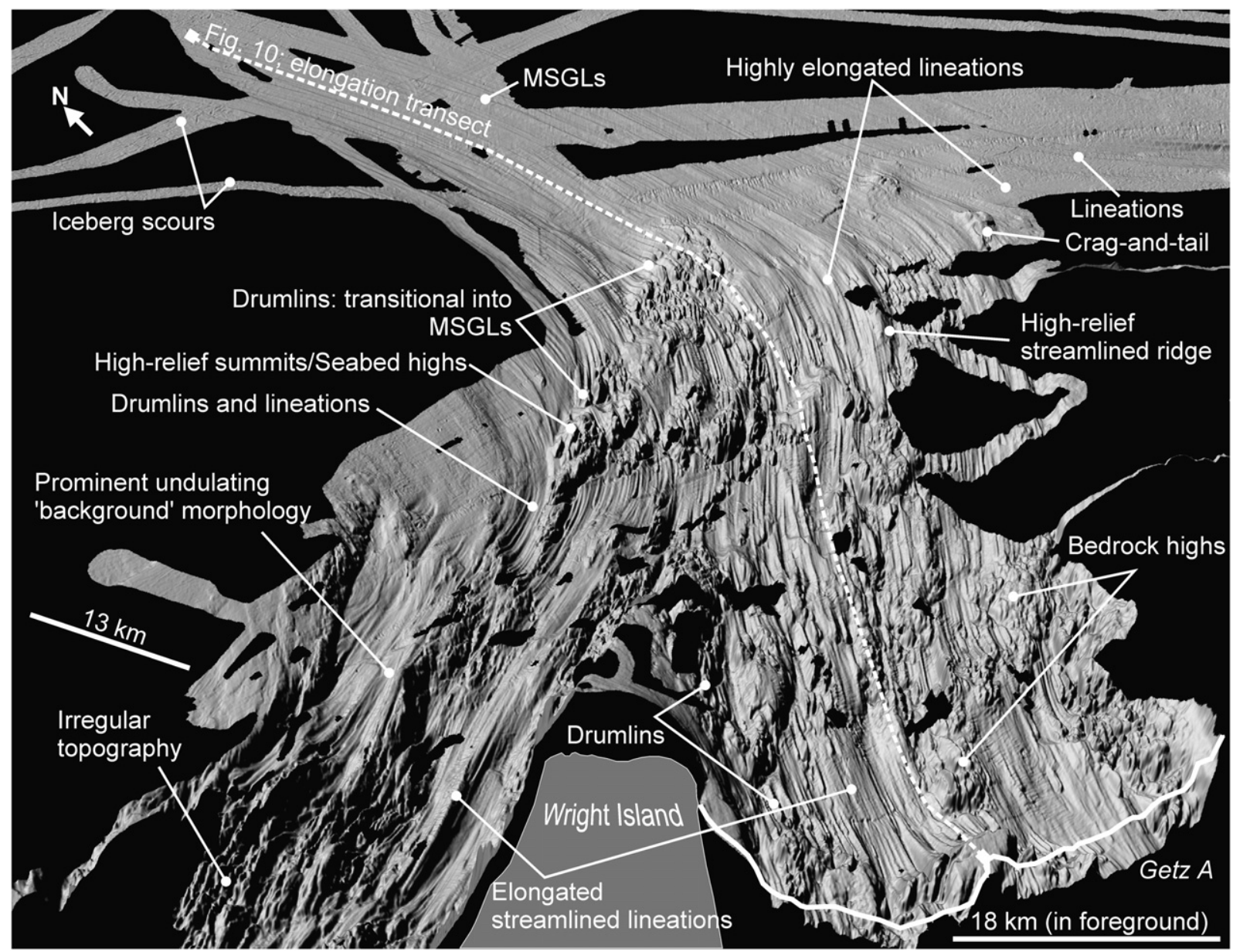

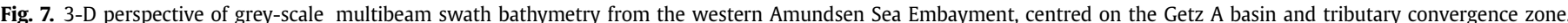

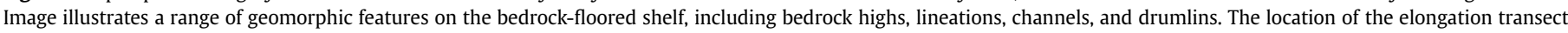
(Fig. 10) is shown. Illumination from NW. Grid cell size $50 \mathrm{~m}$.

\subsection{Landform distribution and landsystems}

To further investigate bedform variability, we mapped the detailed distribution of landforms on the western ASE shelf, which comprises more than 4000 elements (Fig. 11; available as a largeformat map in Fig. S5). Our mapping was restricted to only simple descriptive classes to avoid over-interpretation (i.e. 'streamlined bedform' includes all bedrock lineations as well as MSGLs; see Table 2). Instead, we adopted a landsystem approach for interpreting their distribution (Eyles, 1983; Evans, 2007; Golledge et al., 2008), in so doing separating the features into five groups (Fig. 12).

\subsubsection{Landsystem 1 - meltwater flow}

This group includes open, exposed or partially-filled tunnel valleys and meltwater channels on the inner shelf (Fig. 12A), formed exclusively in bedrock. Subglacial meltwater channels need not necessarily relate to recent phases of glaciation (Lowe and Anderson, 2003; Smith et al., 2009), and thus may be the oldest landsystem on the sea floor, recording inheritance in the ice sheet bed. Several studies show meltwater channels as relict features in bedrock (e.g. Lewis et al., 2006) and subglacial conduits (whether in bedrock or ice) are often regarded to be time-transgressive features (Clark, 1999).

The channels are most abundant at the margins of tributary basins where the highest rates of basal melting are expected associated with: (1) strain heating at shear boundaries (Clark and Stokes, 2003; Schoof, 2004); and (2) basal hydrological gradients driving water towards the ice stream margins. The presence of meltwater channels on the inner shelf may reflect both the impermeability of the substrate and the resistance of the bed to further erosion by other processes (i.e., preservation). The contrasting absence of meltwater features on the sedimentary substrate may further suggest that: (1) any meltwater drainage to the middle and outer shelf occurred prior to the last phase of ice streaming, which obliterated pre-streaming morphological signatures on the 'soft' substrate; (2) subglacial meltwater flow occurred at transient times, when the grounding line was located on bedrock substrate; or (3) drainage was not through a well developed channel system likely to leave a geomorphic imprint, but rather through widely-distributed shallow canals or as Darcian flow through porous sediment (Walder and Fowler, 1994; Ó Cofaigh et al., 2002; Murray et al., 2008).

\subsubsection{Landsystem 2 - composite sub-ice sheet bedforms}

A composite bedform assemblage overprints the rough bedrock on the inner shelf (Fig. 12B). The main characteristics of the landsystem are: (i) a wide spatial variety of bedforms; (ii) a wide range of elongation ratios; (iii) highly irregular topography; and (iv) local highs with an absence of subglacial bedforms, low bedform elongations, or bedforms with different orientations, suggesting that some are relict features. The lack of a consistent geographical pattern to bedform geometry points to local variability in substrate properties, or time-dependent ice flow characteristics - i.e. 

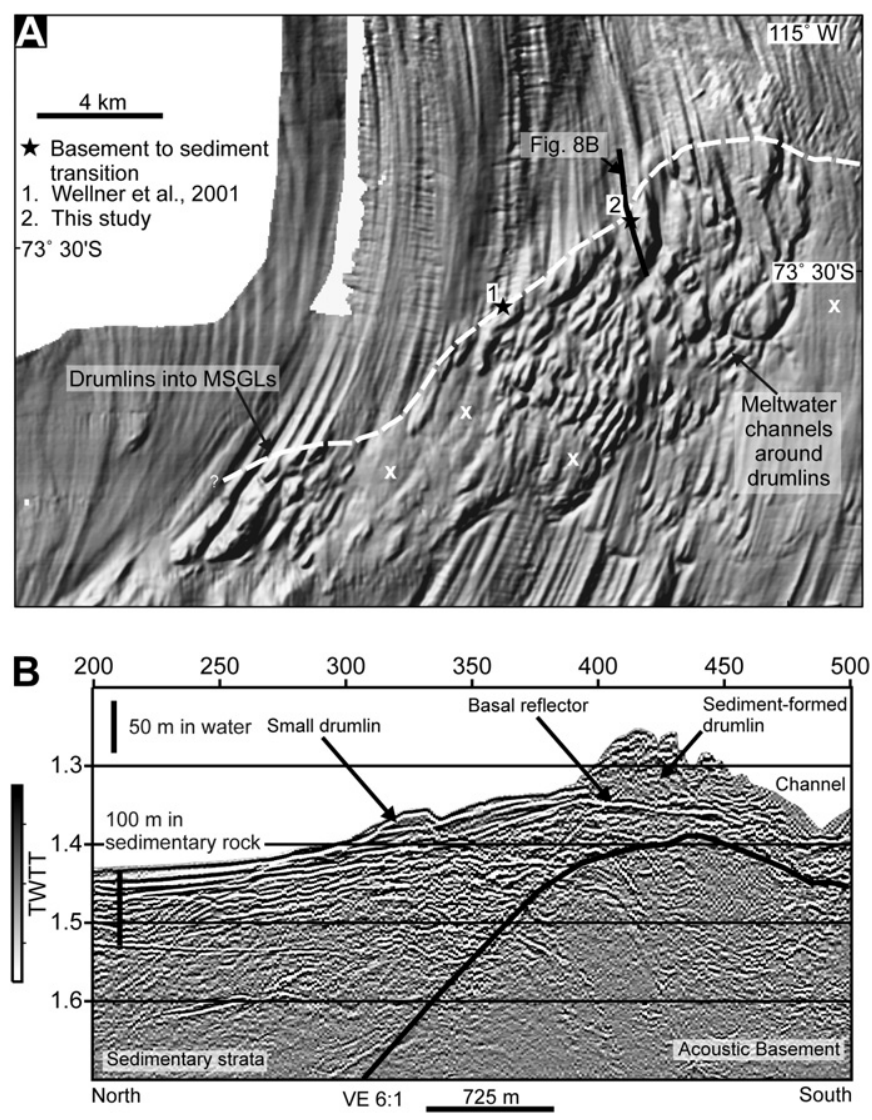

Fig. 8. (A) EM120 multibeam swath bathymetry at the boundary between acoustic basement and sedimentary strata on the western Amundsen Sea continental shelf. Two seismic lines (labelled $1 \& 2$ ) constrain the boundary at points marked by stars. Drumlins characterise the seaward-most portions of the bedrock domain, while MSGLs occur over areas of sedimentary strata. Located in Fig. 2A; (B) F-K migrated singlechannel marine-seismic profile through the long-axis of a single drumlin at the sediment-basement transition. The internal acoustic structure of the drumlin suggests it is formed of relatively high acoustic impedance sediments. A distinct tail and basal reflector are imaged on this profile. Palaeo-ice flow direction is $\mathrm{N}$ in Fig. 8A. VE, vertical exaggeration.

multiple phases of formation; some features formed by full ice stream flow, some formed by accelerating flow, and some unrelated to ice velocity.

Indeed, the erosion of the larger lineations into bedrock probably required a sustained duration of ice sheet cover. Even in the most active modern temperate valley glaciers, long-term erosion of underlying crystalline bedrock occurs at an estimated rate of $\sim 0.1-$ $9 \mathrm{~mm} \mathrm{yr}^{-1}$ (Hallet et al., 1996; Koppes and Hallet, 2006; c. 1-90 m of erosion over 10,000 years). Laberg et al. (2009) suggest that for large palaeo-ice sheets glacial erosion rates are expected to lie at the lower end of this bracket (c. $0.1-2.4 \mathrm{~mm} \mathrm{yr}^{-1}$ ). Therefore, the larger features (200 $\mathrm{m}$ high) in our study area would require persistently high erosion rates to form within one glacial period, while some lower relief bedforms may have formed more quickly. Fast, wet-based ice flow promotes strong erosion, so regardless of duration, ice streams are likely to have carried out the majority of bed modification in this landsystem.

\subsubsection{Landsystem 3 - sub-ice stream footprint}

MSGLs comprising landsystem 3 occur exclusively over sedimentary substrate (Fig. 12C). The downstream change in elongation ratio of subglacial bedforms at the substrate boundary results from a change in basal conditions, from motion over bedrock surfaces, to motion upon a less resistant sedimentary bed. Unlike landsystem 2, mean elongation in landsystem 3 is likely to be a more reliable proxy for palaeo-ice velocity (Stokes and Clark, 2002), and thus, the MSGLs record rapid flow similar to that of modern ice streams (Bamber et al., 2000; King et al., 2009).

MSGLs occur in the top of a soft, deformation till unit, interpreted elsewhere to have been deposited when the last ice sheet had advanced over the continental shelf (Shipp et al., 1999; Ó Cofaigh et al., 2002, 2005a, b; Canals et al., 2000; Dowdeswell et al., 2004; Evans et al., 2005a). The pristine preservation of the MSGLs in the western ASE, coupled with their acoustic and sedimentary stratigraphy, suggest that they record a sub-ice stream footprint formed late during the last glacial period (Fig. 12C), presumably at or immediately after the LGM.

\subsubsection{Landsystems 4 and 5 - ice marginal and pro-marginal assemblages}

Superimposed on the inner and middle shelf bedforms are a series of GZWs formed at the grounding line of the western ASE ice sheet (Fig. 12D). The termination of lineations at their crests indicates that the GZWs formed during a phase of ice margin retreat. Their preservation also implies no further readvances beyond these marginal limits after formation (Todd et al., 2007). If these features are younger than many of the bedrock lineations and the MSGLs mapped elsewhere on the shelf, then they must relate to the last deglaciation accordingly. The GZWs comprise stand-alone bodies of till advected to the ice margin, or form the downstreamfacing ramp of more extensive till sheets (O'Brien et al., 1999; Shipp et al., 1999; Larter and Vanneste, 1995). The sediments required for their formation during the deglaciation may have been supplied by erosion of bedrock bedforms on the inner shelf, suggesting further time-transgressive modification of landsystem 1 .

Iceberg ploughmarks eradicate any MSGLs in shallower water depths than $\sim 700-750 \mathrm{~m}$ in the ASE (Fig. 12D). The majority probably formed during the last deglaciation (Dowdeswell and Bamber, 2007), and thus they record the most recent (proglacial) phase of shelf evolution. Iceberg scours are confined to regions of 'softer' substrate and rarely manifest on the lithologically 'stronger' inner shelf sea floor, even where bathymetry is shallow.

\subsection{Reconstruction of palaeo-ice stream flow}

Detailed mapping of bedforms in a continuous cross-shelf trough has yielded results consistent with a previous interpretation that these form a complex palaeo-ice stream landsystem in the western ASE (Stokes and Clark, 1999; Larter et al., 2009). Larter et al. (2009) summarised that the shelf downflow of the bedforms mapped in our dataset lacks significant ice marginal geomorphology (e.g. large moraines or GZWs; see O'Brien et al., 1999; Shipp et al., 1999). In an ice stream deforming bed system operating as a sediment conveyer, till accumulation would be expected at the terminal position of the ice stream (Alley et al., 1989). An absence of such accumulations on the outer shelf in the western ASE suggests that the grounding line probably advanced to the shelf break during the LGM, and subsequently retreated rapidly or continuously across the outer shelf (Larter et al., 2009). Provenance changes inferred from clay mineral assemblages in sediment cores from the continental rise offshore from the western ASE suggest a WAIS advance to the shelf break (Hillenbrand et al., 2002), while streamlined bedforms observed on the outer shelf in other parts of the ASE indicate that the grounding line extended to the shelf edge, presumably at the LGM (Evans et al., 2006). Based on this information and our geomorphological mapping, we propose the existence of a $265 \mathrm{~km}$ long and up to $65 \mathrm{~km}$ wide convergent ice stream system in the western ASE during the LGM. Although bedforms are 


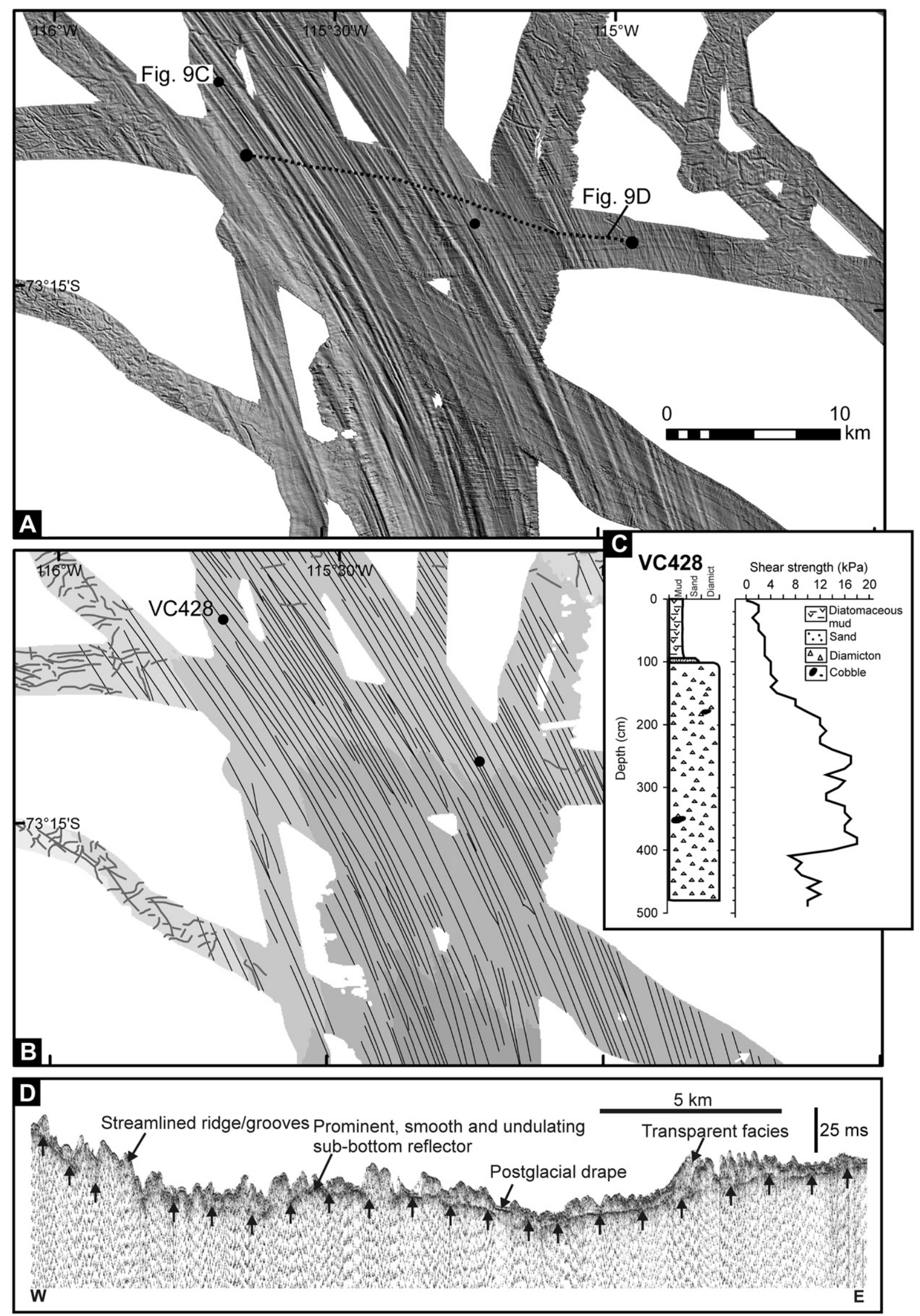

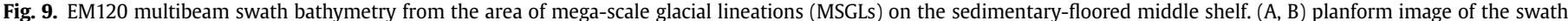

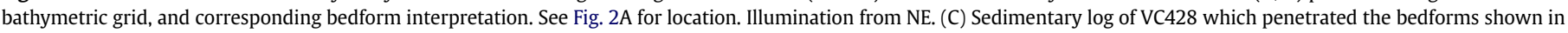

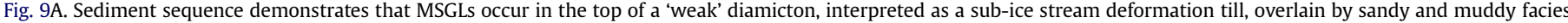

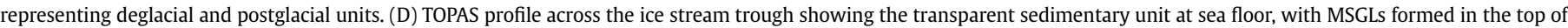
the sediments. The prominent sub-bottom reflector (arrowed) is interpreted as the boundary between the ice stream deformation till and underlying strata. 


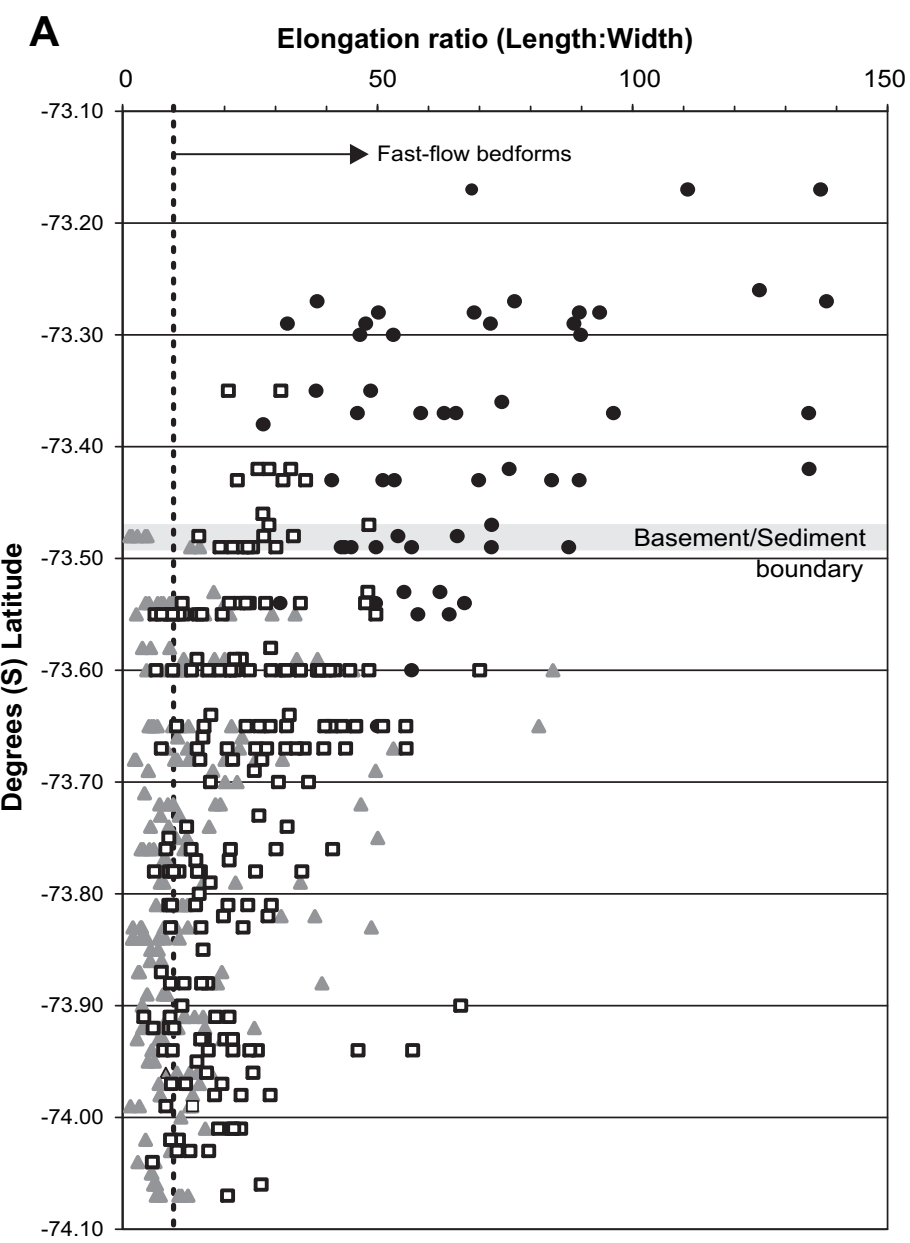

Getz A ice shelf front

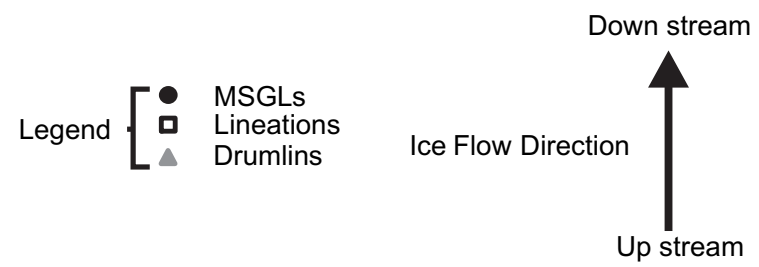

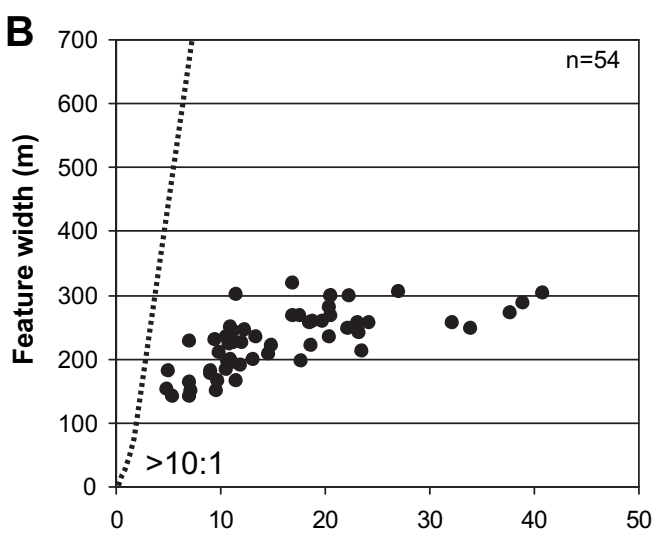
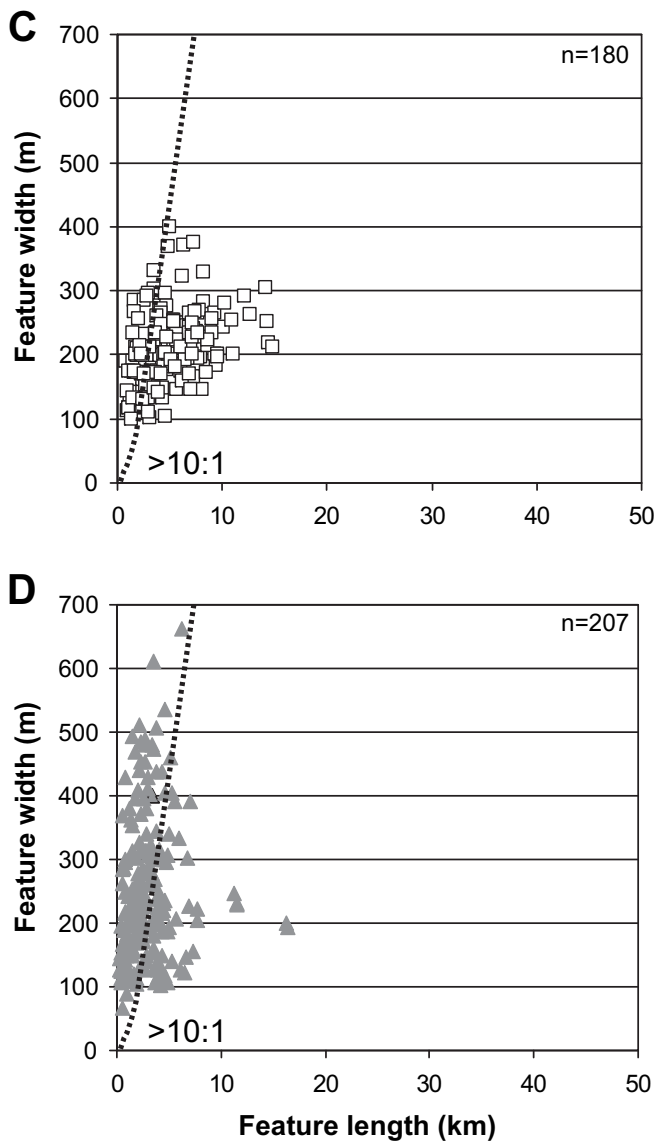

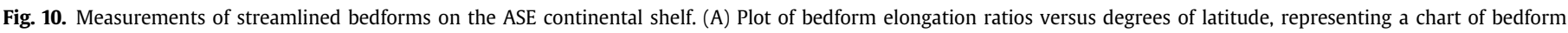

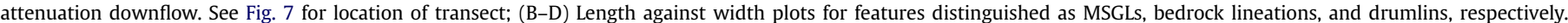

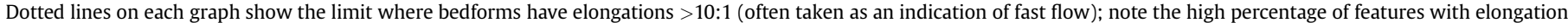

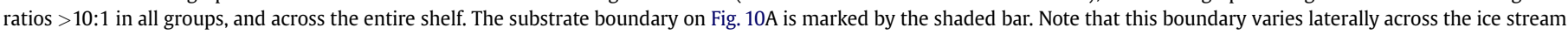
trough, hence some MSGLs appear to fall upon a bedrock substrate in the figure.

complex over our survey area, the majority of glacial lineations form a single major flowset, which suggests that they reflect true lines of palaeo-ice flow (Clark, 1999).

\section{Discussion}

7.1. Multi-temporal record of flow and substrate controls on bedforms

New mapping has revealed that five landsystem assemblages formed during multiple phases of ice sheet development in the western ASE (Figs. 11 and 12). The main changes in complex geomorphology, bed roughness, and bedform elongation occur at the boundary between bedrock and sedimentary strata (Fig. 13). Thus, we conclude that: (i) the bedform signature comprises a multi-temporal record of ice flow; and (ii) that bedform patterns were highly dependent upon the subglacial substrate.

Regional bathymetry suggests that the first-order morphology of the shelf controlled the location of palaeo-ice stream flow in the ASE. The greater thickness of ice occupying the cross-shelf troughs implies that the pressure melting point would have been reached first at these locations. Erosion by streaming flow would have 


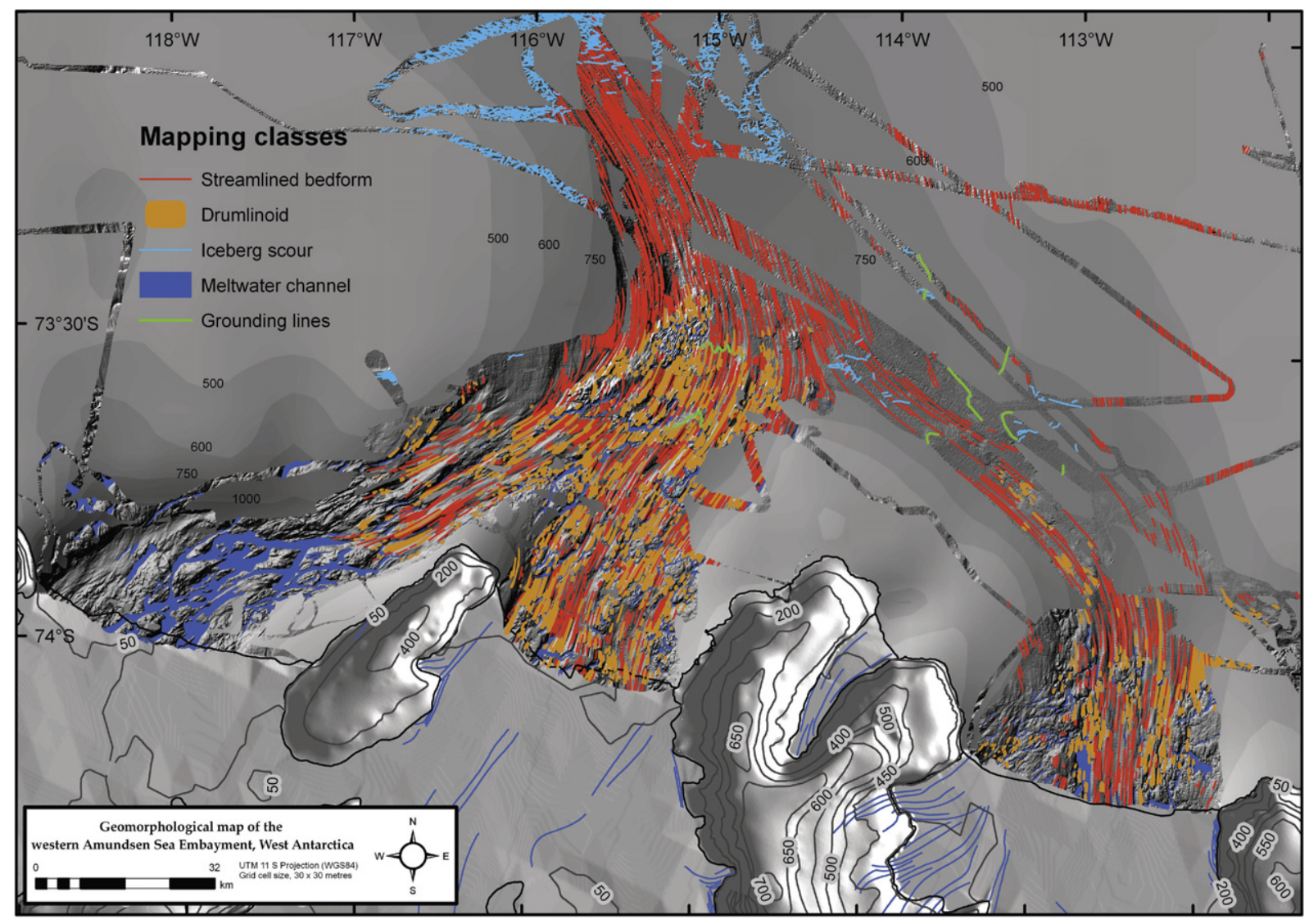

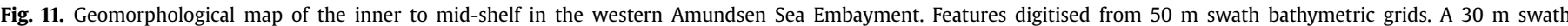

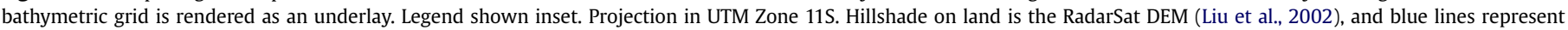
glacial flow lines mapped on satellite images from the Antarctic Digital Database (ADD). Regional bathymetry grid from Nitsche et al. (2007). Depths in metres.

further deepened the troughs through successive glaciations, setting up a positive feedback whereby ice streams were constrained to follow these pathways.

The repeated activity of ice streams on the shelf is recorded in the landsystems from the western ASE. Superimposed landsystems of meltwater flow, composite bedform assemblages, and deglacial landforms characterise the inner shelf, where geomorphological variability is remarkably high (Fig. 13). Locally-restricted bedform elongation continuums (i.e. bedform progressions within subsets of the mapped bedform suite) occur above and across the toes of bedrock highs located between converging ice stream tributaries. The continuums reveal details about local ice flow conditions, not apparent at the scale of regional morphological studies, and lie adjacent to zones with mixed bedforms and elongations.

Clark (1999) provided several criteria, based on northern hemisphere terrestrial bedform mapping, to distinguish a timetransgressive bedform pattern from a bedform pattern formed 'in an instant'. Our inner shelf landsystems can be reliably interpreted as time-transgressive based on observations that: (i) the morphometry of isochronous bedforms should vary systematically and gradually over an ice sheet bed, but our mapping suggests a less well-ordered bedform set with spatial variation and superimposition of landforms (Figs. 10 and 11); (ii) our data indicate lowparallel conformity in bedforms, with some subglacial lineations having slightly different orientations to their neighbours; (iii) the bedform flowset is accompanied by ice marginal retreat features of landsystem 4, that are orthogonal to streamlined landforms; and (iv) the largest inner shelf bedforms form part of the most complex landsystem assemblage, as expected for landforms that have been subject to overriding and erosion, but yet still retain their morphometric signature (Clark, 1999).

In addition, and surprisingly, many parallel and streamlined bedforms in landsystem 2 have elongation ratios $>10: 1$, and thus are diagnostic of formation by fast-flowing ice. Notably, they occur over the entire stretch of the western ASE inner shelf. Numerous landform models have argued that the bedrock-sediment substrate boundary controls the onset of ice stream flow (e.g. Shipp et al., 1999, 2002; Wellner et al., 2001; Canals et al., 2002; Evans et al., 2006; Ottesen et al., 2008), but this appears not to be the case in the western ASE. While we find evidence for flow acceleration in the convergent pattern of bedforms, the onset of past ice streaming was clearly located, at times, much further south of the substrate boundary and likely beneath the ice sheet today. This conclusion is consistent with modern flow rates inferred from remote sensing data, which suggest that limbs of fast-flow originate from deep within the WAIS interior (e.g., Bamber et al., 2000; Joughin et al., 2002). The absence of landforms characteristic of a cold-based thermal regime, such as ribbed moraines (Kleman and Háttestrand, 1999), indicates a wet-based ice stream system, supporting a fastflow interpretation over our entire study area.

The nature of flow over the rough inner shelf topography is likely to echo the variability observed in the bedforms. Crystalline bedrock will not readily supply sediment to a deforming bed layer, so the dominant mechanism of ice flow over this hard substrate was probably via basal sliding (Fig. 13) (Ó Cofaigh et al., 2002). Many bedforms on bedrock surfaces are, thus, attributed to erosion and subglacial moulding during sliding. However, fastflow by sliding requires the existence of a thin subglacial 

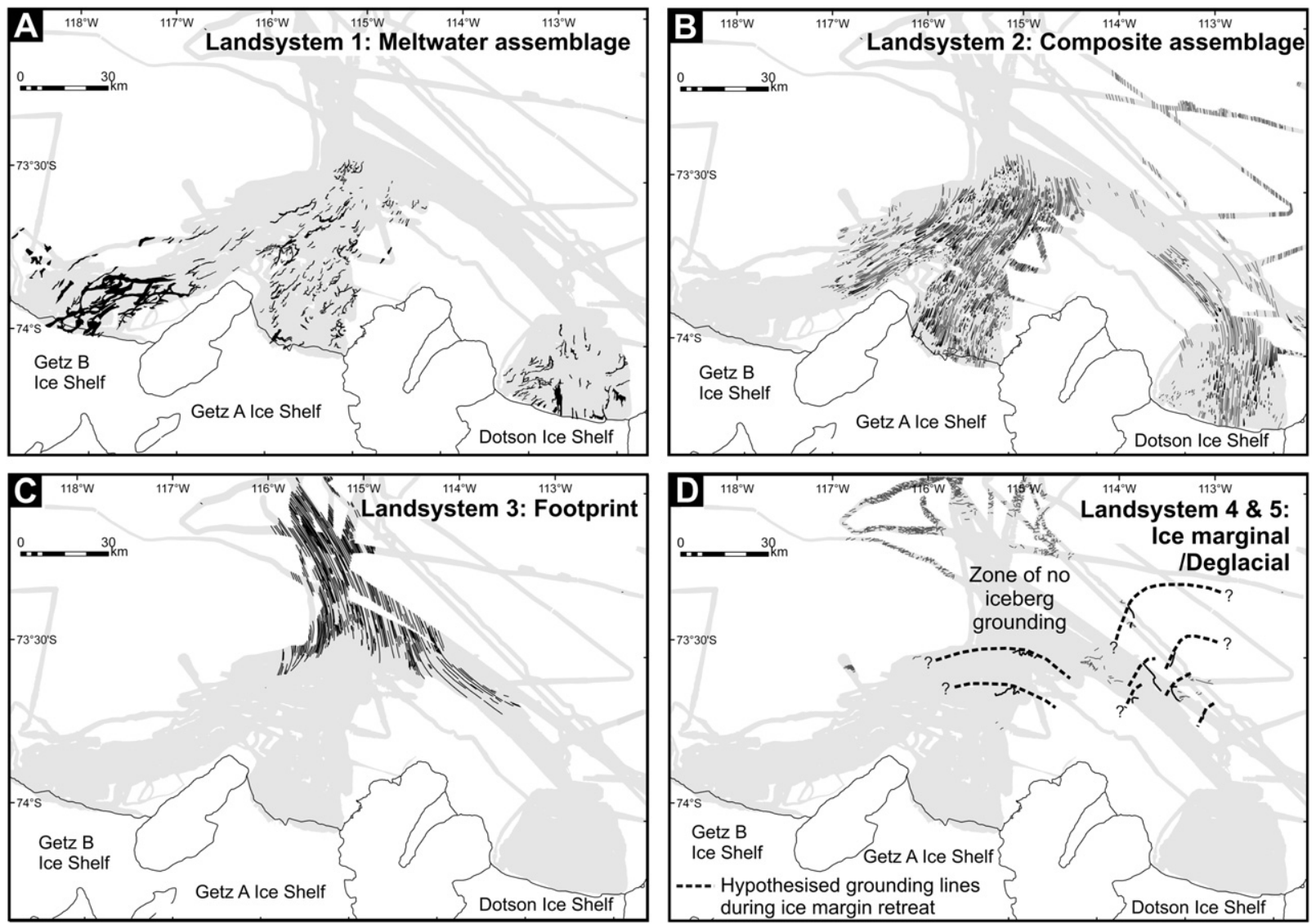

Fig. 12. (A-D) Landsystem groups interpreted from the geomorphology of the continental shelf. See text for full descriptions.

meltwater or sediment layer to lubricate the bed (Kamb, 2001); the presence of both on the inner shelf of the western ASE is evident from abundant meltwater channels and soft till recovered in cores (Smith et al., 2009; Hillenbrand et al., in press). Consequently, from the complexity of the inner shelf geology and its bedform assemblages, we also infer a complicated palaeo-flow regime, consisting of shallow deformation and sliding over water and sediment. The rough, undulating topography of the inner shelf probably favoured locally higher basal shear stresses causing a patchwork of areas with sliding over bare rock zones (i.e., localised regions of higher basal drag, such as sticky spots, Stokes et al., 2007) and areas with enhanced deformation or sliding where 'stick-slip' processes dominated. Zones of smoother, subdued seabed, interspersing lineations and drumlins on the inner shelf (e.g. Fig. 8A), give direct evidence for this ice-bed behaviour, and variability on sub-kilometre scales that is visually indistinguishable from some modern sub-ice stream landscapes (cf. Smith and Murray, 2009; King et al., 2009). These anomalous zones may comprise former areas of basal sliding and higher drag over patches of accumulated stiffer till (overlying bedrock), or localised outcrops of erosionally-smoothed bedrock (Ó Cofaigh et al., 2005a; Smith and Murray, 2009). Indeed, curved tails on some drumlins upstream of larger sea-floor relief (Figs. S2D,F) show that basal ice deflected around local obstacles at the ice-bed, which attests to local variability in the flow of the basal ice layer. Similar 'mosaic' patchworks have been highlighted under contemporary Antarctic ice streams (Smith and Murray, 2009), and northern hemisphere palaeo-ice sheets (Piotrowski et al., 2004), but such complexities have not been proposed for Antarctic palaeo-ice stream systems, to-date.
In contrast to the inner shelf, the MSGLs of landsystem 3 occur over areas of smooth sea floor and sedimentary substrate. The style of bedforms appears to be related to low bed roughness and the widespread presence of more easily erodible sediments, including soft till. These are bed conditions that favour a switch to ice flow dominated by subglacial deformation and generally higher flow velocities (Ó Cofaigh et al., 2007). Thus, the combination of substrate geology and ice flow controlled the imprint of MSGLs on sediments. In recent seismic surveys of the bed of the Rutford Ice Stream, Smith et al. (2007) showed that comparable subglacial bedforms can be constructed and removed on timescales of only a few years. Hence, the majority of the soft-sediment bedforms on a palaeo-ice stream bed would reveal a 'footprint' of the conditions immediately prior to deglaciation rather than during a longer history involving many phases of ice flow. Observations of: (i) high parallel conformity; (ii) few cross-cuts; and (iii) low potential for preservation in MSGLs indicates that they probably formed isochronously, or very nearly (Clark, 1999).

In summary, interlinked controls of substrate and time cause this 'fresh' MSGL footprint on sedimentary strata to differ significantly from a more complex bedform pattern on bedrock topography. Our model does not provide any insight into the relative importance of each control, and we acknowledge that it is difficult to separate out the combined influence of a multi-temporal flow record from complex patchwork bed conditions. However we believe there is good evidence for both having shaped the bedform record on the western ASE shelf. Therefore, our data provide persuasive evidence that subglacial geological conditions modulate the degree to which history and variable flow conditions are represented in the geomorphic signature of this palaeo-ice stream bed. 


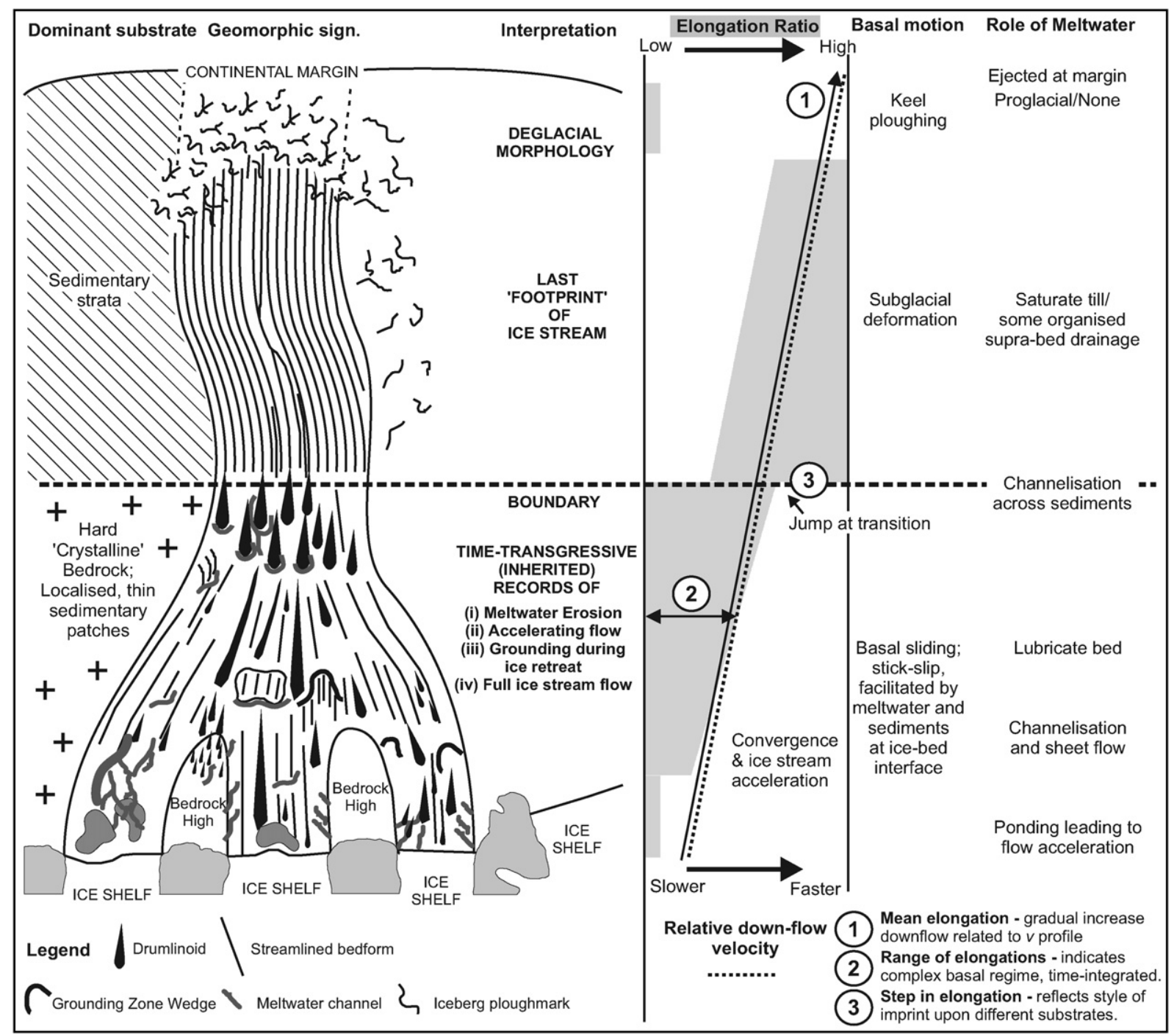

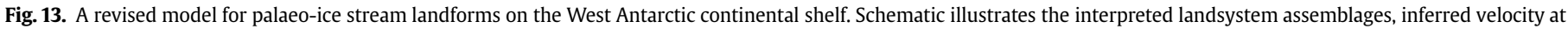
the LGM, a summary of bedform elongation and progression, and the inferred role of meltwater across the shelf. Geomorphic features as mapped in Figs. 11 and 12.

A corollary of our interpretation is that palaeo-ice flow velocities cannot be directly inferred from bedform morphologies, particularly, where these may cross distinct geological boundaries, where the substrate might preserve multiple imprints of past flow, or where datasets may be spatially limited.

\subsection{Comparisons to other landform models}

An implicit assumption of existing Antarctic palaeo-ice stream models is that the bedform progressions record a single snapshot of conditions at the ice stream bed. In our landsystem model, inner shelf bedforms represent a time-integrated signature and are unlikely to have formed immediately prior to deglaciation, like the MSGL footprint (Fig. 12, compare landsystems 2 and 3; Fig. 13). Hence, bedforms should be considered neither necessarily part of a 'final snapshot', nor a component of a simple downflow landform continuum. Furthermore, the erosive capability of ice streams on the inner shelf is perhaps much less than previously assumed (cf. Clark, 1999).

An observation supporting our multi-temporal model is that bedform orientations across bedrock highs and over banks bounding the troughs clearly differ (Fig. S4), which adds further complexity to the landform suite, and suggests that separate generations of sedimentary bedforms did, in fact, form asynchronously. Often overlooked for the Antarctic shelf the observation of multi-generations of bedforms is consistent with palaeo-ice stream beds in the northern hemisphere, where cross-cutting suites of lineations are well mapped (e.g., Stokes and Clark, 2003a; De Angelis and Kleman, 2007). We can explain the preservation of bedforms outside ice stream troughs by a consistent shielding by relatively cold-based, non-erosive ice during the LGM, which is expected for thinner ice occupying inter-stream zones underlain by bathymetric highs (Clark, 1999). Bedforms outside the troughs could thus have formed during earlier glacial episodes, or an earlier stage of the last glacial cycle. Alternatively, some of the bedforms on the middle shelf may have formed synchronously with fast-flow at the LGM, particularly where no cross-cutting is observed and where the change in lineation orientations, from within to outside of the trough, is gradual. However, this idea would invoke 'sheet' flow across some parts of the outer shelf (see Hubbard et al., 2009 for 'sheet' flow analogies), and a flow regime different from anything observed today.

Outside of an Antarctic context, comparison of our palaeo-ice stream model with those from the northern hemisphere highlights 
several differences: (1) the widespread abundance of meltwater channels on the ASE inner shelf suggests an important role for subglacial meltwater at times, when the ice sheet was more extensive, but the origin, flow rates, frequency, and duration of these flows is largely unknown at present (Smith et al., 2009). In contrast, where meltwater landforms have been observed in northern hemisphere palaeo-ice sheets, the routing and function of meltwater is generally better understood (Fisher and Taylor, 2002; Evans et al., 2005b; Hättestrand and Clark, 2006). (2) Cross-cutting bedform sets, highlighting large switches in flow configuration in deglaciating ice sheets, are not apparent in the western ASE as they are in ice stream tracks across North America, the Canadian Shield, and offshore Norway (Stokes and Clark, 2001; Stokes et al., 2009). A more consistent flow regime through time reflecting strong topographic control from subglacial troughs on the shelf, a lack of competing preferential ice flow pathways (unlike West Antarctic Ice Stream C), and consistent sediment delivery through glacial cycles might be reasons for their absence in the ASE. (3) While many bedforms on the northern hemisphere continents can be dated by sediment-landform associations and relationships of cross-cutting bedform flowsets, suitable methods for absolute dating of landforms submerged on the shelf are scarce, and reconciling relative ages of landforms, that often appear overprinted (composite) rather than cross-cut, is difficult. (4) Lastly, some northern hemisphere palaeo-ice streams exhibit strong substrate controls on flow (e.g. Bradwell et al., 2008; Ottesen et al., 2008), but many do not cross a prominent bedrock-sediment boundary like that on the West Antarctic shelf. Indeed, in some cases, subglacial geology had no apparent control on northern hemisphere ice streams (Stokes and Clark, 2003b). Thus, the geomorphic signature of ice streams in the Late Quaternary WAIS may have few modern or palaeo-counterparts. The northern Norway shelf is one notable exception, however, where we observe an analogous crystalline bedrock-to-sedimentary rock substrate transition (Ottesen et al., 2008).

\section{Conclusions}

- A complex arrangement of bedforms mapped across an extensive palaeo-ice stream bed on the continental shelf in the western ASE indicates a multi-temporal record of flow.

- Whereas previous Antarctic landform models have interpreted a single landform progression, the bedforms here can be divided into distinct landform assemblages revealing timetransgressive history for the geomorphology, which implies that bedforms can neither be considered as part of a single downflow continuum nor a direct proxy for palaeo-ice velocity.

- A key control on the bedform imprint is the geology of the shelf, which is divided broadly between rough bedrock on the inner shelf and smooth, dipping, sedimentary strata on the middle to outer shelf. Inner shelf bedform variability is well preserved, revealing information about local, complex basal ice conditions, meltwater flow, and ice dynamics over time, including details not apparent in regional-scale morphological studies.

- From bedform analysis, we conclude that, at times, past ice streams flowed across the entire shelf and had migratory onset zones that often lay within the interior of the Antarctic Ice Sheet today. Variable flow and substrate conditions may have also contributed to the production of a 'mosaic' patchwork bed on the inner shelf.

- Highly elongated mega-scale glacial lineations on sedimentary strata reveal a 'timeslice snapshot' of the last activity of ice streams over the middle to outer shelf, and may be a true representation of palaeo-fast-flow in this location. However, some bedforms outside the main ice stream trough show different orientations and demonstrate multiple generations of sub-ice stream bedforms.

- A revised model for ice stream landforms on the shelf captures complex multi-temporal bedform patterns associated with an Antarctic palaeo-ice stream for the first time. Comparisons with northern hemisphere palaeo-ice sheet beds may offer further insights into ice stream activity in the Late Quaternary WAIS.

\section{Acknowledgements}

This work was supported by the BAS GRADES and AWI MARCOPOLI programs MAR2 and POL6. We thank the captains, officers, crew, technical support staff and shipboard scientists who participated in the two research cruises, particularly Steffen Gauger, Roy Livermore and Tara Deen who processed the multibeam datasets. Staff of the British Geological Survey are acknowledged for operating the seismic and vibrocoring equipment onboard JR141. The manuscript benefited from fruitful discussion with Ed King. We thank Neil Glasser and three reviewers who helped improve the clarity and overall message of the final paper.

\section{Appendix A. Supplemental material}

Supplementary information for this manuscript can be downloaded at doi:10.1016/j.quascirev.2009.07.003.

\section{References}

Alley, R.B., Blankenship, D.D., Rooney, S.T., Bentley, C.R., 1989. Sedimentation beneath ice shelves - the view from ice stream B. Marine Geology 85, 101-120. Anandakrishnan, S., Blankenship, D.D., Alley, R.B., Stoffa, P.L., 1998. Influence of subglacial geology on the position of a West Antarctic ice stream from seismic measurements. Nature 394, 62-65.

Anandakrishnan, S., Catania, G.A., Alley, R.B., Horgan, H.J., 2007. Discovery of till deposition at the grounding line of Whillans Ice Stream. Science 315, 1835-1837. doi:10.1126/science.1138393.

Anderson, J.B., 1999. Antarctic Marine Geology. Cambridge University Press, New York, $289 \mathrm{pp}$.

Anderson, J.B., Oakes-Fretwell, L., 2008. Geomorphology of the onset area of a paleo-ice stream, Marguerite Bay, Antarctic Peninsula. Earth Surface Processes and Landforms 33, 503-512.

Bamber, J.L., Vaughan, D.G., Joughin, I., 2000. Widespread complex flow in the interior of the Antarctic ice sheet. Science 287, 1248-1250.

Bamber, J.L., Ferraccioli, F., Joughin, I., Shepherd, T., Rippin, D.M., Siegert, M.J., Vaughan, D.G., 2006. East Antarctic ice stream tributary underlain by major sedimentary basin. Geology 34, 33-36.

Belderson, R.H., Kenyon, N.H., Wilson, J.B., 1973. Iceberg plough marks in the Northeast Atlantic. Palaeogeography, Palaeoclimatology, Palaeocecology 13, 215-224.

Bennett, M.R., 2003. Ice streams as the arteries of an ice sheet: their mechanics, stability and significance. Earth Science Reviews 61, 309-339.

Bentley, C.R., 1987. Antarctic ice streams: a review. Journal of Geophysical Research 92, 8843-8858.

Blankenship, D.D., Bentley, C.R., Rooney, S.T., Alley, R.B., 1987. Till beneath ice stream B. 1. Properties derived from seismic travel times. Journal of Geophysical Research 92, 8903-8911.

Boulton, G.S., Hindmarsh, R.C.A., 1987. Sediment deformation beneath glaciers: rheology and geological consequences. Journal of Geophysical Research 92, 9059-9082.

Bradwell, T., Stoker, M., Krabbendam, M., 2008. Megagrooves and streamlined bedrock in NW Scotland: the role of ice streams in landscape evolution. Geomorphology 97, 135-156. doi:10.1016/j.geomorph.2007.02.040.

Canals, M., Urgeles, R., Calafat, A.M., 2000. Deep sea-floor evidence of past ice streams off the Antarctic Peninsula. Geology 28, 31-34. doi:10.1130/00917613(2000)028.

Canals, M., Casamor, J.L., Urgeles, R., Calafat, A.M., Domack, E.W., Baraza, J., Farran, M., De Batist, M., 2002. Seafloor evidence of a subglacial sedimentary system off the northern Antarctic Peninsula. Geology 30, 603-606.

Caress, D.W., Chayes, D.N., 2003. MB-System Version 5. http://www.ldeo.columbia. edu/pi/MB-System Open source software distributed from the MBARI and LDEO web sites. 
Clark, C.D., 1993. Mega-scale glacial lineations and cross-cutting iceflow landforms. Earth Surface Processes and Landforms 18, 1-19.

Clark, C.D., 1997. Reconstructing the evolutionary dynamics of former ice sheets using multi-temporal evidence, remote sensing and GIS. Quaternary Science Reviews 16, 1067-1092. doi:10.1016/S0277-3791(97)00037-1.

Clark, C.D., 1999. Glaciodynamic context of subglacial bedform generation and preservation. Annals of Glaciology 28, 23-32.

Clark, C.D., Stokes, C.R., 2003. Palaeo-ice stream landsystem. In: Evans, D.J.A. (Ed.), Glacial Landsystems. Arnold, London, pp. 204-227.

Clark, C.D., Tulaczyk, S.M., Stokes, C.R., Canals, M.C., 2003. A groove-ploughing theory for the production of mega-scale glacial lineations, and implications for ice-stream mechanics. Journal of Glaciology 149, 240-256.

Clark, C.D., Hughes, A.L.C., Greenwood, S.L., Spagnolo, M., Ng, F.S.L., 2009. Size and shape characteristics of drumlins, derived from a large sample, and associated scaling laws. Quaternary Science Reviews 28, 677-692. doi:10.1016/ j.quascirev.2008.08.035

De Angelis, H., Kleman, J., 2007. Palaeo-ice streams in the Foxe/Baffin sector of the Laurentide Ice Sheet. Quaternary Science Reviews 26, 1313-1331.

Dowdeswell, J.A., Bamber, J.L., 2007. Keel depths of modern Antarctic icebergs and implications for sea-floor scouring in the geological record. Marine Geology $243,120-131$.

Dowdeswell, J.A., Ó Cofaigh, C., Pudsey, C.J., 2004. Thickness and extent of the subglacial till layer beneath an Antarctic paleo-ice stream. Geology $32,13-16$.

Engelhardt, H., Humphrey, N., Kamb, B., Fahnestock, M., 1990. Physical conditions at the base of a fast-moving Antarctic ice stream. Science 248, 57-59.

Evans, J., Pudsey, C.J., Ó Cofaigh, C., Morris, P., Domack, E., 2005a. Late Quaternary glacial history, flow dynamics and sedimentation along the eastern margin of the Antarctic Peninsula Ice Sheet. Quaternary Science Reviews 24, 741-774.

Evans, D.J.A., Clark, C.D., Mitchell, W.A., 2005b. The last British Ice Sheet: a review of the evidence utilised in the compilation of the Glacial Map of Britain. EarthScience Reviews 70, 253-312.

Evans, J., Dowdeswell, J.A., Ó Cofaigh, C., Benham, T.J., Anderson, J.B., 2006. Extent and dynamics of the West Antarctic Ice Sheet on the outer continental shelf of Pine Island Bay during the last glaciation. Marine Geology 230, 53-72.

Evans, D.J.A., 2007. Glacial landsystems. In: Knight, P. (Ed.), Glacier Science and Environmental Change, first ed. Blackwell, Oxford, pp. 83-88,. doi:10.1002/ 9780470750636.ch18.

Eyles, N., 1983. Glacial Geology. Pergamon, Oxford, 431 pp.

Fisher, T.G., Taylor, L.D., 2002. Sedimentary and stratigraphic evidence for subglacial flooding, south-central Michigan, USA. Quaternary International 90, 87-115.

Gohl, K. (Ed.), 2007. The Expedition ANTARKTIS-XXIII/4 of the Research Vessel 'Polarstern' in 2006. Reports of Polar and Marine Research, 557. Alfred Wegener Institute for Polar and Marine Research, Bremerhaven, $166 \mathrm{pp}$.

Gohl, K., Teterin, D., Eagles, G., Netzeband, G., Grobys, J.W.G., Parsiegla, N., Schlüter, P., Leinweber, V., Larter, R.D., Uenzelmann-Neben, G., Udintsev, G.B., 2007. Geophysical survey reveals tectonic structures in the Amundsen Sea Embayment, West Antarctica. US Geological Survey Open-File Report 2007, 1047,. doi:10.3133/of2007-1047.srp047.

Golledge, N.R., Finlayson, A., Bradwell, T., Everest, J.D., 2008. The last glaciation of Shetland, North Atlantic. Geografiska Annaler 90, 37-53.

Graham, A.G.C., Lonergan, L., Stoker, M.S., 2007. Evidence for Late Pleistocene ice stream activity in the Witch Ground Basin, central North Sea from 3D seismic reflection data. Quaternary Science Reviews 26, 627-643.

Hallet, B., Hunter, L.E., Bogen, J., 1996. Rates of erosion and sediment evacuation by glaciers: a review of field data and their implications. Global Planetary Change $12,213-235$.

Hättestrand, C., Clark, C.D., 2006. The glacial geomorphology of Kola Peninsula and adjacent areas in the Murmansk Region, Russia. Journal of Maps 2006, 57-69.

Heroy, D., Anderson, J.B., 2005. Ice sheet extent on the Antarctic Peninsula during the last glacial maximum (LGM)-insights from glacial geomorphology. GSA Bulletin 117, 1497-1512.

Hillenbrand, C.-D., Fütterer, D.K., Grobe, H., Frederichs, T., 2002. No evidence for a Pleistocene collapse of the West Antarctic Ice Sheet from continental margin sediments recovered in the Amundsen Sea. Geo-Marine Letters 22, 51-59.

Hillenbrand, C.-D., Baesler, A., Grobe, H., 2005. The sedimentary record of the last glaciation in the western Bellingshausen Sea (West Antarctica): implications for the interpretation of diamictons in a polar-marine setting. Marine Geology 216, 191-204.

Hillenbrand, C.-D., Smith, J.A., Kuhn, G., Esper, E., Gersonde, R., Larter, R.D., Maher, B., Moreton, S., Shimmield, T., Korte, M., in press. Age assignment of a diatomaceous ooze unit deposited in the western Amundsen Sea embayment after the last glacial maximum. Journal of Quaternary Science., in press, doi: 10.1002/ jqs.1308.

Howat, I.M., Domack, E.W., 2003. Reconstructions of western Ross Sea palaeo-icestream grounding zones from high-resolution acoustic stratigraphy. Boreas 32 56-75. doi:10.1080/03009480310001038.

Intergovernmental Panel on Climate Change, 2007. Climate Change 2007: The Physical Science Basis-Summary for Policy Makers. IPCC Secretariat, Geneva, Switzerland. http://www.ipcc.ch/SPM2feb07.pdf.

Jansson, K.N., Stroeven, A.P., Kleman, J., 2003. Configuration and timing of Ungava Bay ice streams, Labrador-Ungava, Canada. Boreas 32, 256-263.

Joughin, I., Tulaczyk, S., Bindschadler, R., Price, S.F., 2002. Changes in West Antarctic ice stream velocities: observation and analysis. Journal of Geophysical Research - Solid Earth 107 (B11), 2289,. doi:10.1029/2001JB001029.
Joughin, I., Rignot, E., Rosanova, C.E., Lucchitta, B.K., Bohlander, J., 2003. Timing of recent accelerations of Pine Island Glacier, Antarctica. Geophysical Research Letters 30 (13), 1706,. doi:10.1029/2003GL017609.

Kamb, B., 2001. Basal zone of the West Antarctic ice streams and its role in lubrication of their rapid motion. In: Alley, R.B., Bindschadler, R.A. (Eds.), The West Antarctic Ice Sheet and Environment. Antarctic Research Series, 77. AGU, Washington, D.C., pp. 157-199.

King, E.C., Woodward, J., Smith, A.M., 2007. Seismic and radar observation of subglacial bed forms beneath the onset zone of Rutford Ice Stream, Antarctica. Journal of Glaciology 53, 665-672.

King, E.C., Hindmarsh, R.C.A, Stokes, C.R., 2009. Formation of mega-scale glacial lineations observed beneath a West Antarctic ice stream. Nature Geoscience 2, 585-588. doi:10.1038/nego581.

Koppes, M., Hallet, B., 2006. Erosion rates during rapid deglaciation in Icy Bay Alaska. F02023. Journal of Geophysical Research: Earth Surface 111 doi:10.1029| 2005JF000349.

Kleman, J., Háttestrand, C., 1999. Frozen-bed Fennoscandian and Laurentide ice sheets during the Last Glacial Maximum. Nature 402, 63-66.

Laberg, J.S., Eilertsen, R.S., Vorren, T.O., 2009. The paleo-ice stream in Vestfjorden, north Norway, over the last 35 k.y.: glacial erosion and sediment yield. GSA Bulletin 121, 434-447. doi:10.1130/B26277.1.

Larter, R.D., Vanneste, L.E., 1995. Relict subglacial deltas on the Antarctic Peninsula outer shelf. Geology 23, 33-36.

Larter, R.D., Rebesco, M., Vanneste, L.E., Gamboa, L.A.P., Barker, P.F., 1997. Cenozoic tectonic, sedimentary and glacial history of the continental shelf west of Graham Land, Antarctic Peninsula. In: Barker, P.F., Cooper, A.K. (Eds.), Geology and Seismic Stratigraphy of the Antarctic Margin, 71. AGU Antarctic Research Series, pp. 1-27. Part 2.

Larter, R.D., Gohl, K., Hillenbrand, C.-D., Kuhn, G., Deen, T.J., Dietrich, R., Eagles, G., Johnson, J.S., Livermore, R.A., Nitsche, F.O., Pudsey, C.J., Schenke, H.-W., Smith, J.A., Udintsev, G., Uenzelmann-Neben, G., 2007. West Antarctic ice sheet change since the last glacial period. Eos, Transactions. American Geophysical Union 88, 189-190. doi:10.1029/2007EO170001.

Larter, R.D., Graham, A.G.C., Gohl, K., Kuhn, G., Hillenbrand, C.-D., Smith, J.A. Deen, T.J., Livermore, R.A., Schenke, H.-W., 2009. Subglacial bedforms revea complex basal regime in a zone of paleo-ice stream convergence, Amundsen Sea Embayment, West Antarctica. Geology 37, 411-414.

Lewis, A.R., Marchant, D.R., Kowalewski, D.E., Baldwin, S.L., Webb, L.E., 2006. The age and origin of the Labyrinth, western Dry Valleys, Antarctica: evidence for extensive middle Miocene subglacial floods and freshwater discharge to the Southern Ocean. Geology 34, 513-516. doi:10.1130/G22145.1.

Liu, H., Jezek, K., Li, B., Zhao, Z., 2002. Radarsat Antarctic Mapping Project digital elevation model version 2. Boulder, CO: National Snow and Ice Data Center Digital media.

Lonergan, L., Maidment, S.C.R., Collier, J.S., 2006. Pleistocene subglacial tunnel valleys in the central North Sea basin: 3-D morphology and evolution. Journal of Quaternary Science 21, 891-903. ISSN: 0267-8179.

Lowe, A.L., Anderson, J.B., 2002. Reconstruction of the West Antarctic ice sheet in Pine Island Bay during the Last Glacial maximum and its subsequent retreat history. Quaternary Science Reviews 21, 1879-1897.

Lowe, A.L., Anderson, J.B., 2003. Evidence for abundant subglacial meltwater beneath the paleo-ice sheet in Pine Island Bay, Antarctica. Journal of Glaciology 49, 125-138.

Mosola, A.B., Anderson, J.B., 2006. Expansion and rapid retreat of the West Antarctic Ice Sheet in Eastern Ross Sea: possible consequence of over extended ice streams? Quaternary Science Reviews 25, 2177-2196.

Murray, T., Corr, H., Forieri, A., Smith, A.M., 2008. Contrasts in hydrology between regions of basal deformation and sliding beneath Rutford Ice Stream, West Antarctica, mapped using radar and seismic data. Geophysical Research Letters 35, L12504. doi:10.1029/2008GL033681.

Nitsche, F.O., Cunningham, A., Larter, R.D., Gohl, K., 2000. Sedimentation processes in the Bellingshausen Sea and their variations along the continental margin. Marine Geology 162, 277-302.

Nitsche, F.O., Jacobs, S.S., Larter, R.D., Gohl, K., 2007. Bathymetry of the Amundsen Sea continental shelf: implications for geology, oceanography and glaciology. Geochemistry, Geophysics, Geosystems 8, Q10009. doi:10.1029/2007GC001694.

O’Brien, P.E., De Santis, L., Harris, P.T., Domack, E.W., Quilty, P.Q., 1999. Ice shelf grounding zone features of western Prydz Bay Antarctica: sedimentary processes from seismic and sidescan images. Antarctic Science 11, 78-91.

Ó Cofaigh, C., 1996. Tunnel valley genesis. Progress in Physical Geography 20,1-19.

Ó Cofaigh, C., Pudsey, C.J., Dowdeswell, J.A., Morris, P., 2002. Evolution of subglacial bedforms along a palaeo-ice stream, Antarctic Peninsula continental shelf. Geophysical Research Letters 29. doi:10.1029/2001GL014488.

Ó Cofaigh, C., Dowdeswell, J.A., Allen, C.S., Hiemstra, J.F., Pudsey, C.J., Evans, J., Evans, D.J.A., 2005a. Flow dynamics and till genesis associated with a marinebased Antarctic palaeo-ice stream. Quaternary Science Reviews 24, 709-740.

Ó Cofaigh, C., Larter, R.D., Dowdeswell, J.A., Hillenbrand, C.-D., Pudsey, C.J., Evans, J., Morris, P., 2005b. Flow of the West Antarctic Ice Sheet on the continental margin of the Bellingshausen Sea at the Last Glacial Maximum. Journal of Geophysical Research: Solid Earth 110, B11103.

Ó Cofaigh, C., Evans, J., Dowdeswell, J.A., Larter, R.D., 2007. Till characteristics, genesis and transport beneath Antarctic paleo-ice streams. Journal of Geophysical Research: Earth Surface 112, F03006.

Ottesen, D., Dowdeswell, J.A., Rise, L., 2005. Submarine landforms and the reconstruction of fast-flowing ice streams within a large Quaternary ice sheet: The 
2500-km-long Norwegian-Svalbard margin $\left(57^{\circ}-80^{\circ} \mathrm{N}\right)$. Geological Society of America Bulletin 117, 1033-1050.

Ottesen, D., Stokes, C.R., Rise, L., Olsen, L., 2008. Ice-sheet dynamics and ice streaming along the coastal parts of northern Norway. Quaternary Science Reviews 27, 922-940. doi:10.1016/j.quascirev.2008.01.014.

Peters, L.E., Anandakrishnan, S., Alley, R.B., Winberry, J., Voigt, D.E., Smith, A.M Morse, D.L., 2006. Subglacial sediments as a control on the onset and location of two Siple Coast ice streams, West Antarctica. Journal of Geophysical Research 111, B01302. doi:10.1029/2005JB003766.

Piotrowski, J.A., Larsen, N.K., Junge, F.W., 2004. Reflections on soft subglacial beds as a mosaic of deforming and stable spots. Quaternary Science Reviews 23, 993-1000.

Pudsey, C.J., Barker, P.F., Larter, R.D., 1994. Ice sheet retreat from the Antarctic Peninsula shelf. Continental Shelf Research 14, 1647-1675. doi:10.1016/02784343(94)90041-8.

Rignot, E., 2008. Changes in West Antarctic ice stream dynamics observed with ALOS PALSAR data. Geophysical Research Letters 35, L12505,. doi:10.1029/ 2008GL033365.

Rignot, E., Jacobs, S.S., 2002. Rapid bottom melting widespread near Antarctic Ice Sheet grounding lines. Science 296, 2020-2023.

Rippin, D.M., Bamber, J.L., Siegert, M.J., Vaughan, D.G., Corr, H.F.J., 2006. Basal conditions beneath enhanced-flow tributaries of Slessor Glacier, East Antarctica. Journal of Glaciology 52, 481-490.

Schoof, C., 2004. On the mechanics of ice stream shear margins. Journal of Glaciology 50, 208-218.

Shepherd, A., Wingham, D., Rignot, E., 2004. Warm ocean is eroding West Antarctic Ice Sheet. Geophysical Research Letters 31, L23402,. doi:10.1029/2004GL021106.

Shipp, S., Anderson, J., Domack, E.W., 1999. Late Pleistocene-Holocene retreat of the West Antarctic Ice-Sheet system in the Ross Sea: Part 1-Geophysical results. Geological Society of America Bulletin 111, 1486-1516. doi:10.1130/0016-7606.

Shipp, S., Wellner, J.S., Anderson, J.B., 2002. Retreat signature of a polar ice stream: sub-glacial geomorphic features and sediments from the Ross Sea, Antarctica. In: Dowdeswell, J.A., Ó Cofaigh, C. (Eds.), Glacier-Influenced Sedimentation on High-Latitude Continental Margins. Geological Society, vol. 203. Special Publications, London, pp. 277-304.

Siegert, M.J., Taylor, J., Payne, A.J., Hubbard, B., 2004. Macro-scale bed roughness of the Siple Coast Ice Streams in West Antarctica. Earth Surface Processes and Landforms 29, 1591-1596.

Smith, A.M., Murray, T., 2009. Bedform topography and basal conditions beneath a fast-flowing West Antarctic ice stream. Quaternary Science Reviews 28, 584-596. doi:10.1016/j.quascirev.2008.05.010.

Smith, A.M., Murray, T., Nicholls, K.W., Makinson, K., Adalgeirsdottir, G., Behar, A., Vaughan, D.G., 2007. Rapid erosion, drumlin formation, and changing hydrology beneath an Antarctic ice stream. Geology 35, 127-130. doi:10.1130/G23036A.1.

Smith, J.A., Hillenbrand, C.-D., Larter, R.D., Graham, A.G.C., Kuhn, G., 2009. The sediment infill of subglacial meltwater channels on the West Antarctic continental shelf. Quaternary Research 71, 190-200.

Stoker, M.S., Pheasant, J.B., Josenhans, H., 1997. Seismic methods and interpretation. In: Davies, T.A., Bell, T., Cooper, A.K. (Eds.), Glaciated Continental Margins. An Atlas of Acoustic Images. Chapman and Hall, London, pp. 9-26.
Stokes, C.R., Clark, C.D., 1999. Geomorphological criteria for identifying Pleistocene ice streams. Annals of Glaciology 28, 67-74.

Stokes, C.R., Clark, C.D., 2001. Palaeo-ice streams. Quaternary Science Reviews 20, 1437-1457.

Stokes, C.R., Clark, C.D., 2002. Are long subglacial bedforms indicative of fast ice flow? Boreas 31, 239-249.

Stokes, C.R., Clark, C.D., 2003a. The Dubawnt Lake palaeo-ice stream: evidence for dynamic ice sheet behaviour on the Canadian Shield and insights regarding the controls on ice-stream location and vigour. Boreas 32, 263-279.

Stokes, C.R., Clark, C.D., 2003b. Laurentide ice streaming on the Canadian Shield: a conflict with the 'soft bedded' ice stream paradigm? Geology 31, 347-350.

Stokes, C.R., Clark, C.D., Lian, O., Tulaczyk, S., 2007. Ice stream sticky spots: a review of their identification and influence beneath contemporary and palaeo-ice streams. Earth Science Reviews 81, 217-249.

Stokes, C.R., Clark, C.D., Storrar, R., 2009. Major changes in ice stream dynamics during deglaciation of the north-western margin of the Laurentide Ice Sheet. Quaternary Science Reviews 28, 721-738.

Todd, B.J., Valentine, P.C., Longva, O., Shaw, J., 2007. Glacial landforms on German Bank, Scotian Shelf: evidence for Late Wisconsinan ice-sheet dynamics and implications for the formation of De Geer moraines. Boreas $36,148-169$.

Uenzelmann-Neben, G., Gohl, K., Larter, R.D., Schlueter, P., 2007. Differences in ice retreat across Pine Island Bay, West Antarctica, since the Last Glacial Maximum: Indications from multichannel seismic reflection data, U.S. Geological Survey Open-File Report, srp084. http://pubs.usgs.gov/of/2007/1047/srp/srp084. doi:10.3133/of2007-1047, doi:10.3133/of2007-1047.srp084

Vanneste, L.E., Larter, R.D., 1995. Deep-tow boomer survey on the Antarctic Peninsula Pacific margin: an investigation of the morphology and acoustic characteristics of late Quaternary sedimentary deposits on the outer continental shelf and upper slope. In: Cooper, A.K., Barker, P.F., Brancolini, G. (Eds.), Geology and Seismic Stratigraphy of the Antarctic Margin. Antarctic Research Series, vol. 68. American Geophysical Union, Washington, DC, pp. 97-121.

Vaughan, D.G., 2008. West Antarctic Ice Sheet collapse - the fall and rise of a paradigm. Climatic Change 91, 69-75.

Vaughan, D.G., Arthern, R., 2007. Why is it hard to predict the future of ice sheets? Science 315, 1503-1504. doi:10.1126/science.1141111.

Walder, J.S., Fowler, A., 1994. Channelised subglacial drainage over a deformable bed. Journal of Glaciology 40, 3-15.

Weigelt, E., Gohl, K., Uenzelmann-Neben, G., Larter, R.D. Late Cenozoic ice sheet cyclicity in the western Amundsen Sea Embayment - evidence from seismic records. Global and Planetary Change. in press, doi:10.1016/j.gloplacha.2009. 07.004.

Wellner, J.S., Lowe, A.L., Shipp, S.S., Anderson, J.B., 2001. Distribution of glacial geomorphic features on the Antarctic continental shelf and correlation with substrate: implications for ice behaviour. Journal of Glaciology 47, 397-411.

Wellner, J.S., Heroy, D.C., Anderson, J.B., 2006. The death mask of the Antarctic ice sheet: comparison of glacial geomorphic features across the continental shelf. Geomorphology 75, 157-171. 